\title{
Tracing the Influence of Ming-Qing Buddhism in Early Modern Japan: Yunqi Zhuhong's Tract on Refraining from Killing and on Releasing Life and Ritual Animal Releases
}

\author{
Barbara R. Ambros
}

Citation: Ambros, Barbara R.. 2021. Tracing the Influence of Ming-Qing Buddhism in Early Modern Japan: Yunqi Zhuhong's Tract on Refraining from Killing and on Releasing Life and Ritual Animal Releases. Religions 12: 889. https://doi.org/10.3390/ rel12100889

Academic Editor: Jeffrey L. Richey

Received: 6 September 2021

Accepted: 3 October 2021

Published: 15 October 2021

Publisher's Note: MDPI stays neutral with regard to jurisdictional claims in published maps and institutional affiliations.

Copyright: (C) 2021 by the author Licensee MDPI, Basel, Switzerland. This article is an open access article distributed under the terms and conditions of the Creative Commons Attribution (CC BY) license (https:// creativecommons.org/licenses/by/ $4.0 /)$
Department of Religious Studies, University of North Carolina, Chapel Hill, NC 27599-3225, USA; bambros@email.unc.edu

Abstract: This essay traces the Japanese reception of Zhuhong's Tract on Refraining from Killing and on Releasing Life in the early modern period. Ritual animal releases have a long history in Japan beginning in the seventh century, approximately two centuries after such rituals arose in China. From the mid-eighth century, the releases became large-scale state rites conducted at Hachiman shrines, which have been most widely studied and documented. By contrast, a different strand of life releases that emerged in the Edo period owing to the influence of late Ming Buddhism has received comparatively little scholarly attention despite the significance for the period. Not only may the publication of a Sino-Japanese edition of Zhuhong's Tract in 1661 have been an impetus for Shogun Tokugawa Tsunayoshi's Laws of Compassion in the late-seventeenth century, but also approximately thirty Japanese Buddhist texts inspired by Zhuhong's Tract appeared over the next two and a half centuries. As Zhuhong's ethic of refraining from killing and releasing life was assimilated over the course of the Edo and into the Meiji period, life releases became primarily associated with generating merit for the posthumous repose of the ancestors although they were also said to have a variety of vital benefits for the devotees and their families, such as health, longevity, prosperity, and descendants.

Keywords: life releases; animals; Buddhism; Yunqi Zhuhong; Laws of Compassion; morality books; merit ledgers; upoṣadha days

\section{Introduction}

In his Sankyō hōjō benwaku (Clarification of life releases in the Three Teachings, 1803), the Shingon cleric Kanjun retold one of the most popular karmic tales from Yunqi Zhuhong's Jiesha fangsheng wen (Tract on refraining from killing and on releasing life, 1584) in the Japanese vernacular:

In the Great Ming, the husband and wife of a certain Cheng family loved eating turtles. One time, they were able to obtain a large soft-shell turtle. They gave it to the kitchen maid and told her, "Go and cook it." Then, the master and mistress left. The kitchen maid saw that the soft-shell turtle was afraid that she would kill it and tried to run away, and she felt pity for it. When she released it in a pond near the house, it looked joyful and disappeared into the depth of the pond. Afterward, when the master and mistress said, "Serve the cooked turtle", the kitchen maid replied, "It ran away." Then they became very angry and caned the kitchen maid in harsh punishment. After some time had passed, the kitchen maid suffered from an illness and ran a high fever due to an epidemic. When she was about to die, the people in the household were afraid she would pass the illness to them. They took her to a small hut by the side of the pond and left her there to die. That night, the soft-shell turtle that the maid had released earlier came out of the pond carrying mud and smeared it over the body of the kitchen maid. It was as if it knew that she was extremely ill. The fever gradually 
subsided. The master and mistress found it strange that the maid had not died and sent someone to ask. The kitchen maid told them what had happened. The master and mistress were still in doubt and went to investigate that evening, but it was as the kitchen maid had said. [The turtle] carried mud and smeared it on the body of the maid. Thus, the maid gradually recovered from her illness. When the master and mistress saw this, they could not help but be moved. From then on, they did not eat soft-shell turtle again. (Kanjun 1803, pp. II.1a-1b)

By Kanjun's time, Zhuhong's Tract had been assimilated widely in Japan and had become a resource for heart-wrenching karmic tales that illustrated the ethic of refraining from killing and releasing life. Along with Ming-Qing morality books and merit ledgers, Zhuhong's Tract spurred the publication of approximately thirty Buddhist texts on the topic of refraining from killing and releasing life from approximately the time when Shogun Tsunayoshi promulgated the Laws of Compassion until Japan transitioned into modernity in the Meiji period (1868-1912). ${ }^{1}$

Ritual life releases (Ch. fangsheng; J. hōjō) have a long history in Japan beginning in the seventh century, approximately two centuries after such rituals arose in China. From the mid-eighth century, the releases became large-scale state rites conducted at Hachiman shrines, which were combinative multiplexes that amalgamated the worship of kami and buddhas. Of these, the release at the Iwashimizu Hachiman Shrine, first held in 863 , was the grandest in scale and has been most widely studied and documented. By contrast, a different strand of devotional, small-scale life releases that emerged in the Edo period owing to the influence of late Ming Buddhism has received comparatively little scholarly attention. In surveying the works of Zhuhong (1535-1615) that were published in Sino-Japanese during the Edo period (1603-1868), Araki Kengo remarks that it is difficult to accurately assess the societal influence of Zhuhong's Tract on Refraining from Killing and on Releasing Life (Okada and Araki 1984, pp. 4-5). Yet, over the past four decades, scholars have demonstrated how seminal Zhuhong and his Tract were for revitalizing and popularizing life releases among Ming-Qing literati (Yü [1981] 2020; Handlin Smith 2009; Eichman 2016). Japanese scholars have also begun to assess the influence of Zhuhong's Tract in the Edo period (Nishimura 2012, 2014, 2016; Nogawa 2016b).

In this essay, I will build on these scholars' research to investigate the reception of Zhuhong's Tract in early modern Japan and its influence on lay-oriented doctrine and practice, which illustrates the acculturation of Ming-Qing Buddhism in Japan beyond the development of the Ōbaku school and Ōbaku's impact on Zen monasticism. During this period, Japanese Buddhist clerics of several different denominations adapted Zhuhong's Tract, first through reprinting, translation, and commentary from the mid-seventeenth through the mid-eighteenth centuries and then through texts that were more loosely inspired by Zhuhong's work from the late-eighteenth through the late-nineteenth century. As Zhuhong's ethic of refraining from killing and releasing life was assimilated and spread among townspeople over the course of the Edo and into the Meiji period, life releases became primarily associated with accruing merit for the posthumous repose of the ancestors although they were also said to generate a variety of vital benefits for devotees and their families, such as health, longevity, prosperity, and descendants.

\section{The Transmission of Zhuhong's Ethic of Refraining from Killing and Releasing Life}

In the late Ming dynasty, the Buddhist cleric Zhuhong was a strong proponent of vegetarianism and ritual animal releases for the laity. Zhuhong was born in Hangzhou in 1535 as the eldest son of the prominent Shen family. He studied Confucianism until he was thirty-two years old but also developed an interest in Daoism and Buddhism. As a young adult, he started reciting Amitabha Buddha's name and promoted the Taiwei xianjun gongguo ge (Ledger of merits and demerits according to the immortal Taiwei), a popular Daoist merit ledger from the Song dynasty. Having lost several family members to death and lacking success in the examination system, he took the tonsure at the age of thirty-two and studied with several Chan masters. He returned to Hangzhou in 1571 and revitalized 
Yunqi Monastery. Zhuhong became a local Buddhist leader who promoted a blend of Chan and Pure Land Buddhism and revitalized the monastic precepts at his temple. Yunqi Monastery, where Zhuhong remained until his death in 1615, had been founded in 967 by Chan Master Zhifeng, who was known for his ability to tame tigers. Likewise, Zhuhong was said to have distinguished himself by successfully conducting rain-making rituals and controlling local tiger violence by performing esoteric rituals for hungry ghosts. He also developed a dedicated lay following among Ming literati by promoting life releases (Yü [1981] 2020, pp. 20-37, 82). In addition to referring to life releases in many of his writings, he composed two texts that were exclusively devoted to the topic. The first was Fangsheng yi (Rite for releasing life; J.32, no. B277, vol. 10), which was inspired by a liturgy composed by the Tiantai cleric Siming Zhili (960-1028) and became the standard liturgy for life releases during the Qing dynasty (Stevenson 2004b, p. 395). This text, however, did not circulate in early modern Japan.

The second work was Tract on Refraining from Killing and on Releasing Life, which became very influential in the Edo period. Zhuhong's Tract consists of two parts: a tract on refraining from killing and a tract on releasing life. Based on examples from the Chinese classics and Buddhist texts, the tract on refraining from killing made a reasoned argument against taking life and eating meat on the occasion of life-cycle celebrations and ancestral rites, as a cure for illness, or to make a living. In the tract on releasing life, Zhuhong illustrated his argument for conducting life releases with twenty-eight graphic tales that either were excerpted from older Buddhist, Daoist, and Confucian sources or were eyewitness accounts set in the recent past. These tales demonstrated the agreement of the Three Teachings on releasing life and engaged the reader affectively. Both tracts concluded with dedications of merit that practitioners were supposed to recite before a Buddhist image in order to report their success at avoiding killing and releasing life and to pray for rebirth in Amitabha's Western Pure Land (J.32, no. B277, vol. 11; Stevenson 2004a).

Thanks to Zhuhong, life releases became popular in late Ming and Qing literati circles as practitioners reconciled this Buddhist ritual with their identity as Confucian scholars. Zhuhong's Tract was reprinted more than twenty times, and his lay disciples formed societies that organized regular animal releases, maintained life-releasing ponds, and established sanctuaries for terrestrial animals (Eichman 2016, pp. 122, 172-80, 202-4). Life releases, which had previously been sporadic observances, became a frequent topic of interest in written records produced by Ming and Qing literati. As Joanna Handlin Smith notes, most of the releases focused on small animals because the literati perceived such releases both as a metaphor for charity toward vulnerable elements of society and as a way to assert their own status (Handlin Smith 2009, pp. 15-16, pp. 35-41). At the same time, charitable activities, including life releases, afforded upwardly mobile, wealthy merchants an opportunity to gain social respectability as they used their wealth for the public good (Brokaw 1991, pp. 13, 207-16).

With the fall of the Ming dynasty, Buddhist clerics from southern China-most prominently Yinyuan Longqi (1592-1673), who established the Ōbaku Zen school-migrated to Japan. As a young man, before he became ordained as a monk, Yinyuan had been an enthusiastic practitioner of life releases, so much so that he was said to have squandered his family fortune buying animals in the market in order to release them. Once he took the tonsure, he continued to organize life releases. After he arrived in Japan, he even conducted a life release ritual on behalf of Shogun Ietsuna during a three-month stay in Edo in 1658. At the Ōbaku temple Manpukuji in Kyoto, Yinyuan established monthly release rituals, a lotus society dedicated to holding such rituals, and a life release pond (Wu 2014). In 1661, the year of Manpukuji's founding, Zhuhong's Tract on Refraining from Killing and on Releasing Life was published as a Sino-Japanese (Jpn. kanbun) edition funded by a Hayashi Jinbee, a disciple from Nagasaki, who wished to spread Zhuhong's Tract to encourage people to develop compassion and cease killing. The edition reproduced Zhuhong's Tract in Chinese with guiding marks to facilitate converting the text into Japanese while reading (Figure 1). The edition also included an appendix composed by Yinyuan that consisted 
of two gāthās promoting life releases and refraining from killing, as well as an afterword (Zhuhong 1661).

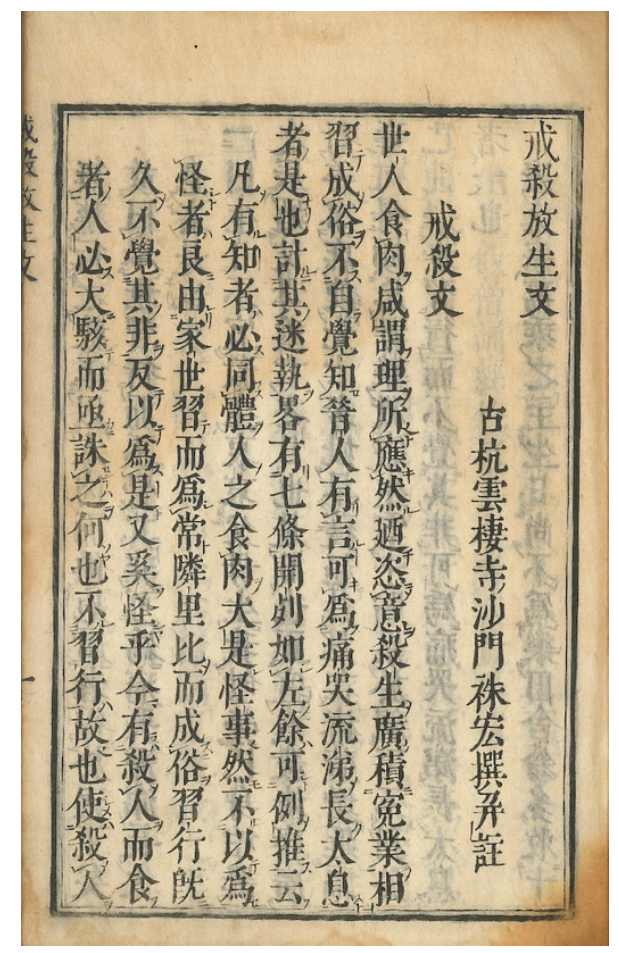

Figure 1. The opening page of the Sino-Japanese edition of Zhuhong's Tract on Refraining from Killing and on Releasing Life (1661). Zhuhong's text is reproduced in Chinese with Japanese reading guides. (Original in author's collection.)

Several other writings of Zhuhong's that supported the ethic of refraining from killing and releasing life were also transmitted to Japan around this time. The three volumes of Zhuchuang suibi (Jottings by a bamboo window, 1615), which contained short sections arguing against killing and meat eating, appeared as a Sino-Japanese edition in 1653 . The three volumes of Yigao (Posthumous papers), which contained two brief items on life releases, were published as a Sino-Japanese edition in 1694 in Kyoto. Additionally, a SinoJapanese edition of Zhuhong's Zizhi lu (Record of self-knowledge; 1604), a merit ledger that listed the merits and demerits of specific actions including those affecting animals, appeared in 1660 but the text was not widely circulated until a second Sino-Japanese edition was published in 1701 during Shogun Tsunayoshi's reign (Okada and Araki 1984, pp. 3-6; Zhuhong 1701). Zhuhong's Record of Self-Knowledge text led to several vernacular Japanese editions from the early eighteenth through the mid-nineteenth centuries. By contrast, there seems to be no early modern vernacular edition of the Posthumous Papers, and a vernacular edition of Jottings by a Bamboo Window titled Chikusō zuihitsu wage (Japanese translation of jottings by a bamboo window) did not appear until 1884 (Kasama 1884).

\section{The Ethic of Refraining from Killing and Releasing Life and Tsunayoshi's Laws of Compassion}

Zhuhong's ethic of refraining from killing and releasing life, in particular its articulation in Tract, may have influenced the Laws of Compassion for Living Beings promulgated by Shogun Tsunayoshi (1646-1709; r. 1680-1709). Over the course of his reign, Tsunayoshi issued numerous edicts that prohibited the mistreatment and killing of animals, from cutting horses' sinews to produce a desirable gait or abandoning ill horses to killing dogs or fishing without a license. After Tsunayoshi's death, the edicts were quickly repealed and generally condemned as excessively harsh toward the human perpetrators. Why Tsunayoshi promulgated the laws has been debated for centuries. Popular rumor had it 
that Tsunayoshi issued the edicts, especially those protecting dogs, because he was born in the year of the dog and desired the birth of an heir, and that his mother's Buddhist preceptor, the Shingon cleric Ryūkō (1649-1724), had recommended the Shogun adopt a policy of refraining from killing. Modern scholars have argued, however, that Tsunayoshi was primarily motivated by Neo-Confucianism and that his promotion of benevolence toward animals served to control the violent impulses of the warrior class (Bodart Bailey 1985).

Recently, some scholars have hypothesized that Zhuhong's ethic of refraining from killing and releasing life may also have been a factor in Tsunayoshi's policies. Nogawa Hiroyuki has compiled circumstantial evidence for Zhuhong's influence on Tsunayoshi's edicts. While there are no extant records that Tsunayoshi had direct access to Zhuhong's Tract, Tsunayoshi could have been exposed to the ethic of refraining from killing and releasing life through multiple channels of contact with Ōbaku clerics. During Yinyuan's visit to Edo in 1658 in order to thank Shogun Ietsuna for allowing him to propagate the Buddhist teachings, Tsunayoshi was only thirteen years old and probably too young for the encounter to have left a significant impression, but Tsunayoshi also met Yinyuan's disciple and successor, Muan Xingtao (1611-1684), in 1665 when the latter visited Edo to thank Shogun Ietsuna for allowing him to succeed Yinyuan. In addition, Tsunayoshi's mother Keishōin interceded on behalf of the Ōbaku cleric Kōon Dōkai (1628-1695), who was Yinyuan and Muan's disciple, when he published a controversial text and was nearly exiled from his domain in 1682. Furthermore, Tsunayoshi had a cordial relationship with Yanagizawa Yoshiyasu (1658-1714), who was an avid lay practitioner of Zen and had close personal connections to Chinese Ōbaku clerics beginning in 1692. While these contacts do not provide conclusive evidence that Tsunayoshi encountered Zhuhong's teachings and the ethic of refraining from killing and releasing life, the repeated interactions of the Shogun and his inner circle with Ōbaku clerics leaves open the possibility that he encountered the topic in conversation or through sermons. In addition to the Obaku connections, Nogawa also notes that in 1679, Ietsuna had reinstated the life release at the Iwashimizu Hachiman Shrine after a hiatus of approximately 200 years, and that in the late seventeenth century, the Tendai school developed an interest in the Tiantai patriarch Zhiyi's role in the development of life release ponds; thus, Tsunayoshi may also have encountered the topic through his contacts with the high-ranking Tendai clerics who were close to the Tokugawa family (Nogawa 2016b).

Indeed, during Tsunayoshi's reign, the shogunate occasionally released animals. For instance, between 1688 and 1693, the shogunate released falcons, which had been used by the Shogun for hunting, in the mountains in Musashi Province near Edo before officially abolishing the shogun's falconry altogether. In 1703, a variety of birds and beasts (such as deer, weasels, cats, falcons, eagles, kites, crows, ducks, pheasants, herons, quail, and pelicans) were released in numerous locations, primarily in the Kantō region. Whether such releases involved a ritual component is unclear; however, some animals that required continued care were also released at shrines and temples. For instance, chickens were released in the precincts of the Shiba Shinmei Shrine, Kanda Myōjin Shrine, Fukagawa Hachiman Shrine, and the Tendai temple Sensōji in Edo, whereas goldfish and silvercolored fish were released into the pond of Yugyōji, a Ji sect temple in Fujisawa, Sagami Province. A similar release of fish had been ordered by the shogunate in 1694, when the fish had been collected from townspeople in Edo for release in Yugyoji's pond. It became clear in the following year that weasels and pelicans had preyed on these fish because the pond was overcrowded; therefore, the shogunate ordered the construction of a new pond adjacent to the old one and had the fish moved there (Nesaki 2006, pp. 200-4).

In addition to suggesting that Zhuhong's Tract may have inspired Tsunayoshi's Laws of Compassion, Nishimura Ryō has also noted the popularity of Ming-Qing morality books and merit ledgers that promoted the performance of good deeds and the overlap in content with the Laws of Compassion. The Ming-Qing morality books and merit ledgers that circulated in Japan during this period included Zhuhong's Record of Self-Knowledge, which appeared in a second Sino-Japanese edition in 1701 during Tsunayoshi's reign. This second 
edition was published by the Jōdo scholar monk Ninchō (1645-1711), who had received copies of Zhuhong's Record and Yuan Liaofan's Yinzhi lu (Record of hidden recompense), another popular Ming-dynasty morality book, from Duzhan Xingying (1628-1706), the fourth abbot of the Ōbaku temple Manpukuji. Ninchō was a promoter of monthly life releases at the Iwashimizu Hachiman Shrine and worked on his Iwashimizu hōjōe ki (Record of the Iwashimizu life release) until the end of his life. His Sino-Japanese edition of Zhuhong's Record of Self-Knowledge spurred the publication of several vernacular abridged and full editions from the early eighteenth through the first half of the nineteenth centuries (Nishimura 2014; Zhuhong 1701). Yanagida Naomi argues that morality books such as Zhuhong's Record of Self-Knowledge inculcated support for Tsunayoshi's authority as an absolute ruler and, conversely, that the Laws of Compassion were meant to compel people to perform good deeds in the spirit of benevolence and compassion as promoted in these texts (Yanagida 2015). In other words, the morality books and the Laws of Compassion had conceptual overlap and reinforced each other. Indeed, some of these instructions resemble the injunctions imposed by the Law of Compassion; however, whereas the morality books implied karmic consequences and punishments meted out by an other-worldly bureaucracy, Tsunayoshi's edicts were enforced by worldly authorities.

Zhuhong's Record of Self-Knowledge was heavily influenced by Daoist morality books and merit ledgers that practitioners used to keep score of their good and bad deeds. These morality books and merit ledgers were reflective of a popular religiosity that merged elements from the Three Teachings (Confucianism, Daoism, and Buddhism). One early prototype, Taishang ganying pian (Treatise of the exalted one on response and retribution), combined Daoist ideas of a heavenly bureaucracy that kept a record of people's conduct and bestowed punishments on offenders with a Confucian morality that included taboos against the excessive exploitation of animals as means to demonstrate benevolence. Another merit ledger, which enjoyed much popularity in the Ming dynasty and directly inspired Zhuhong's Record of Self-Knowledge, was the twelfth-century Daoist Ledger of Merits and Demerits According to the Immortal Taiwei. Zhuhong had first encountered this ledger before he took the tonsure and adapted its method of record-keeping of merits and demerits to Buddhism in his Record of Self-Knowledge (Yü [1981] 2020, pp. 106-39).

Like the Daoist ledgers on which it was modeled, Zhuhong's Record of Self-Knowledge included injunctions to promote kindness toward animals and stem violence against them. Merit-generating acts of kindness included deeds such as saving animals from death; prohibiting or discouraging animal slaughter, hunting, and fishing; burying dead animals and conducting memorial services for them to assist in their salvation; and abstaining from eating meat. ${ }^{2}$ Conversely, harmful acts that accrued demerit included killing or harming the health of animals; killing and turning animals into food or medicine; raising and then selling animals to a butcher; witnessing and not preventing the killing of animals; selling the meat of animals after they died naturally; causing excessive suffering and pain when cooking animals; causing physical harm to animals; training animals for hunting; disturbing hibernating, nesting, or burrowing animals; causing harm to unborn animals in eggs or in the womb; caging or tethering animals; supporting blood offerings to divinities; and eating meat. In assigning merits and demerits to such actions, Zhuhong differentiated between animals based on their size and whether they could return human kindness. For example, he posited that the life of an animal that could return human kindness (that is, horses, oxen, and dogs) counted as twenty merits if rescued and twenty demerits if killed; an animal that could not return human kindness (such as pigs, deer, ducks, and geese) counted as ten; a small animal counted as one, and ten very small animals (such as insects) counted as one (Yü [1981] 2020, pp. 234-55; J.32, no. B277, vols. 8 and 9).

Whatever the influence of this Ming-Qing morality book literature may have been on Tsunayoshi's policies, the 1661 Sino-Japanese edition of Zhuhong's Tract triggered the publication of approximately thirty Japanese Buddhist texts whose cultural force outlasted Tsunayoshi's short-lived Law of Compassion. These publications included a variety of genres such as anthologies, karmic tale collections, and ritual texts on life 
releases that appeared over the next two and a half centuries, beginning with Asai Ryōi's Kaisetsu hōjō monogatari (Tale of refraining from killing and releasing life, 1664), a vernacular rendition of Zhuhong's Tract, and ending with Taikyo's Hōjō meikan roku (Record of the supernatural recompense of life releases, 1898). The texts published between the midseventeenth century and the mid-eighteenth century reproduced Zhuhong's Tract through vernacular adaptation and commentary whereas Zhuhong's influence was more diffuse in later works. Even though Tsunayoshi's edicts of compassion were repealed soon after his death, Zhuhong's ethic of refraining from killing and releasing life had a lasting effect from the Edo into the late Meiji period.

These various works on refraining from killing and releasing life were compiled by clerics from a variety of Buddhist denominations, including the Jōdo, Jōdo Shin, Sōtō, Shingon, and Tendai schools, suggesting that the ethic of refraining from killing and releasing life had a trans-sectarian appeal that ran counter to the increasing sectarianism of the period. Zhuhong's syncretic approach combining Zen and Pure Land as well as drawing on the Three Teachings to provide universal support for the ethic of refraining from killing and releasing life lent itself to adaptation across various Buddhist schools, as did its strong lay appeal. As distinct sectarian identities solidified during the seventeenth and eighteenth centuries, the Buddhist clerics promoting life releases shaped Zhuhong's message to fit their sectarian priorities but ultimately tended to take inclusive positions rather than strictly adhering to sectarianism, and clerics of different denominations often referenced one another's works. As Buddhism came to dominate funerary practices in the Edo period, life releases also became especially associated with generating merit for the ancestors.

\section{First Engagements: Vernacular Editions, Commentary, and Abridged Versions}

In the first century after Zhuhong's Tract was first introduced to Japan, Japanese Buddhist clerics devised different ways of presenting the text to a Japanese readership. The 1661 Sino-Japanese version, which added syntactic and inflective markers that allowed readers to instantaneously translate the Chinese text into Japanese, made the work accessible to a highly literate audience of Buddhist clerics and scholars but provided no annotations and little help with complex Chinese characters or references to the classics. In order to make the work more accessible to novice readers, two vernacular editions appeared: the Jōdo Shin cleric Asai Ryōi's Tale of Refraining from Killing and Releasing Life and the Sōtō Zen affiliated Zuda Zenseki's Kaisetsu hōjō mon wage (Japanese translation of the tract on refraining from killing and releasing life, 1744). Conversely, two Sino-Japanese works were targeted at monastic and scholarly audiences: the Shingon Ritsu cleric Enkyō's Kaisetsu hojjo mon sange (Commentary on the tract on refraining from killing and releasing life, 1682), a line-by-line lexigraphical commentary, and the Sōtō cleric Dokuan Genkō's Kaisetsu hōjō mon hen (Anthology of tracts on refraining from killing and releasing life, 1692), a compendium that included an abridged version of Zhuhong's Tract alongside other Song through Ming works on refraining from killing and releasing life.

Asai Ryōi (1612-1691) was a Jōdo Shin priest and popular author of books written in the vernacular syllabic script. He may have been the son of a Jōdo Shin cleric in Ōsaka and served as the abbot of Hōshōji, a Jōdo Shin temple in Kyoto (Hōjō 1973). Ryōi is widely credited with the authorship of the Tale of Refraining from Killing and Releasing Life, the first Japanese vernacular adaptation of Zhuhong's Tract. ${ }^{3}$ Ryōi's Tale consists of four volumes with pictorial illustrations of the karmic tales and was based on the 1661 Sino-Japanese edition because it also includes Yinyuan's gāthās and a summary of Yinyuan's afterword. In the preface and the afterword, Ryōi explains that his intention was to make the text accessible to novice readers by using the Japanese vernacular so that even women and children could read it with ease. He expressed his hope that the text would touch the hearts of the literate elites and the common people alike, so that its teachings would spread in the world, inspire compassion, and allow people to form karmic bonds that would lead them toward enlightenment (Asai 2013, pp. 430, 484). 
At first glance, Ryōi's vernacular rendition appears to be a Japanese translation of Zhuhong's Tract, and Ryōi's Tale is sometimes catalogued as such, but this is a mischaracterization. Ryōi did not translate the Sino-Japanese version of Zhuhong's Tract verbatim but supplemented the text with diverse material from other Ming-dynasty sources. Chinese reprints of Zhuhong's Tract often featured new prefaces that supplemented the text with karmic tales (Eichman 2016, p. 122). By contrast, Ryōi incorporated the additional tales into the text itself. Ryōi added nine karmic tales to the two volumes on refraining from killing in a similar manner in which Zhuhong had illustrated the section on releasing life. He also added another nine tales to the two volumes on releasing life, substituting several of Zhuhong's original tales. Ryōi's Tale must have been more intelligible, culturally relevant, and emotionally engaging for a broad Japanese audience than Zhuhong's original Tract, which relied heavily on literary and historical allusions.

Ryōi did not identify his supplementary sources, but much of the additional material came from two Ming-dynasty sources: Yan Maoyou's Diji lu (Record of gaining good fortune, 1634) and Yiyuan Zongben's Guiyuan zhizhi ji (Pointing directly to the return to the origin, 1553; X.61, no. 1156). Ryōi borrowed seven tales from Record of Gaining Good Fortune, and another five tales from Zhuhong's Tract overlapped with Yan's compendium, which was already known in Japan shortly after it appeared in the late Ming dynasty. For instance, Record of Gaining Good Fortune served as the crucial source for Nakae Tōju's Kagami gusa (1647), which was arguably the first morality book published in Japan. Ryōi himself was familiar with Record of Gaining Good Fortune as it influenced several other works he composed around this time, such as Kannin ki (Chronicle of patience, 1659) and Ukiyo monogatari (Tales of the floating world, 1666) (Ogawa 1975, 1993; Kimura 2018; Dong 2018a, 2018b).

Ryōi drew even more extensively on Zongben's Pointing Directly to the Return to the Origin, which was issued as a Sino-Japanese edition in 1643 and contained several sections on refraining from killing and releasing life. Ryōi incorporated several tales from Zongben's text into the Tale and also shaped his own argument for the ethic of refraining from killing and releasing life based on Zongben's text. In total, Zongben's influence is traceable in eighteen sections of Ryōi's Tale. In addition, Ryōi appears have excerpted a few tales from Taiping guangji (Extensive records of the Taiping era), which was completed in 978 but gained popularity when it was reprinted in the late Ming dynasty (Kimura 2018).

By combining these Chinese sources, Ryōi adapted them to make his Tale of Refraining from Killing and Releasing Life culturally relevant for his seventeenth-century Japanese audience. The section entitled "You Should Not Kill Living Beings When Worshipping the Ancestors" is a good example that illustrates Ryōi's strategy. Zhuhong's original text presents a critique of Confucian ancestral sacrifices:

Point three: It is not appropriate to take life in order to make sacrificial offerings to ancestral forebears. On death anniversaries, and at the spring and autumn grave-side offerings, one should refrain from killing in order to provide blessings in the netherworld. Taking life in sacrificial offering merely increases [evil] karma, nothing more. When the eight precious objects are arrayed before you, how are you ever going to raise their bones from the nine springs and enable them to eat it? This kind of offering is utterly without benefit, and in fact causes harm. Those who are wise do not engage in it. The fact that the whole world engages in this without realizing its error is surely a third example of something so painful that one weeps endlessly with grief. (Stevenson 2004a, pp. 410-11)

As is the case with every section in Zhuhong's Tract, this main text is followed by a paragraph of commentary, in which Zhuhong includes allusions to the Confucian classicsthe Book of Changes and the Record of Rites-and a reference to Emperor Wu of the Liang replacing blood sacrifices with vegetarian offerings. Zhuhong's Tract thus necessitated some familiarity with the Confucian classics and with Chinese history.

The corresponding passage in Ryōi's text is strikingly different from this section of Zhuhong's Tract. Ryōi contrasted Chinese and Japanese customs of commemoration but 
did not suggest in any way that Japanese customs were morally superior. Instead, both could be karmically damaging if they involved killing animals:

In China, people kill birds, fish, oxen, sheep, and the like and offer such dishes in worship on memorial days and death anniversaries. This is similar to a Buddhist service to mourn the dead according to the Buddha dharma.

That being the case, in Japan, when worshipping the ancestors, people used to offer fish and fowl in the past, but since the Buddha dharma was transmitted to our country, people observe a vegetarian abstinence in worship and have a Buddhist monk recite scriptures and generate merit. Since it is the custom in our country to perform Buddhist rituals, people are sure to buy fish and fowl and eat them until the early evening before the memorial day. Or once the Buddhist rituals have ended, they quickly kill fish and fowl the next morning and eat them. This is truly heartless and negates the wholesomeness of the performance so that it has no merit.

Master Hanshan said, "Observing a fast yesterday and killing the six domestic animals today. Once making heaven and a hundred times hell."

Even though they make offerings to the Buddha, have a Buddhist monk officiate, hold a fast, and recite scriptures, people already incur one hundred parts of sin by killing living beings before one part of merit has not even been completed. In this way, how is this supposed to benefit the deceased? Conversely, it increases the hindrances of sin and causes suffering for the deceased.

If you kill living beings and eat them before conducting Buddhist rituals, you have already committed a sin while you have not practiced good deeds yet. If you quickly kill living beings and eat them after you have conducted Buddhist rituals, you have already added evil deeds while the good deed has not been fully completed yet.

If your intentions are in disorder before and after, how can you deepen the merit accrued on this day? (Asai 2013, p. 437).

Ryōi did not translate Zhuhong's passage in full but summarized Zhuhong's opening and borrowed heavily from Zongben's Pointing Directly to the Return to the Origin to shift the focus from Confucian ancestral sacrifices to Buddhist memorial rituals and merit making. How much Ryōi borrowed from Zongben becomes immediately apparent through juxtaposition with section 81 in Zongben's Pointing Directly to the Return to the Origin:

Someone asked again: "How about the many people in this world who seek to make merit in order to prolong their lives or who conduct Buddhist rituals for a deceased person, but before they have not yet actually made merit, they say it's complete, invite people, kill living beings, prepare a banquet, and entertain a crowd, or afterward, when merit has not been completed yet, recklessly saying to close the hall and appease the gods; that is, they kill living beings, set out alcohol, and hold a feast?" I answered, "They are foolish people. How sad! How painful! For example, it is just like a person who has defiled his body with blood trying to wash himself with blood. They do not know that they are conversely adding to the suffering of the deceased. Therefore, Hanshan and Shide said, "Observing a fast yesterday and killing the six domestic animals today. Once making heaven and a hundred times hell." Alas, how can they make merit for the deceased and overcome yin and exalt yang? If you want to make merit, how can you not refrain from alcohol and, even more so, kill living beings and eat meat? (X.61, no. 1156, 2.0480b16-0481a05)

As Kimura Michiko has noted, the reference to Hanshan is conclusive proof that Ryōi adapted this passage from Zongben (Kimura 2018, p. 74). Moreover, Ryōi's argument resembles the one in Zongben's text. Ryōi shifted the focus from a critique of sacrificial ancestral rites to avoiding the consumption of fish and fowl before and after Buddhist 
memorial services in order to generate more merit for the deceased, which had more cultural relevance in Edo Japan given the prevalence of Buddhist funeral and memorial rites during this period.

In the passage that follows, rather than reproducing Zhuhong's commentary that drew on the Chinese classics and Chinese history, Ryōi continues with two heart-wrenching karmic tales related to memorial observances: (1) a story excerpted from Yan's Record of Gaining Good Fortune about a mother who is reborn as a dog in her previous household and, as a canine, observes fasts on the anniversaries of her previous death and (2) a story adapted from Zongben's Pointing Directly to the Return to the Origin about a mother who hires five monks to recite scriptures on behalf of her deceased daughter, but when only one monk performs the recitation and the five monks then squander the donation on alcohol, the spirit of the deceased appears and laments the karmic damage she has sustained as a result of their conduct, thereby leading the monks to observe the precepts, contemplate the Buddha, and attain enlightenment (Asai 2013, pp. 437-39; Kimura 2018, p. 72). As is apparent from this passage, Ryōi promoted Zhuhong's ethic of refraining from killing and releasing life, but by prioritizing Japanese customs and vivid karmic tales, he rendered it more accessible to novice readers who were likely to be unfamiliar with Chinese customs, history, or literature.

In contrast to Ryōi's version, Zuda Zenseki's Japanese Translation of the Tract on Refraining from Killing and on Releasing Life published eighty years later is a far more faithful rendering of Zhuhong's original Tract. Like Ryōi's Tale, Zenseki's translation was based on the 1661 Sino-Japanese edition as it also includes Yinyuan's gāthās. Little is known about Zenseki; however, the preface to the translation was written by a cleric named Kyōryū from Shūdenji, a Sōtō temple in Miharu Domain in Mutsu Province, and the text was published by Anshōji, a Sōtō Zen temple in the Asakusa neighborhood of Edo. This suggests that Zenseki was also affiliated with Sōtō Zen and connected to sectarian networks in eastern Japan. The author's name may have been a pen name and approximately translates as "shaking off the defilement of desires and accumulating good deeds", which signals the author's commitment to the kind of merit making promoted in early modern morality books.

To illustrate the nature of Zenseki's translation, it is instructive to consider his rendition of the same passage discussed above:

Third, it says: you should not kill to worship your ancestors. On the death anniversary of the deceased or the four times of ancestral worship, you should observe an abstinence to help increase the merit for the deceased. By killing living beings, you primarily increase evil karma needlessly. That is to say, even if you lay out the eight precious objects, how are you going to make the deceased who is trapped in the maze of the Nine Springs eat them? It has absolutely no benefit but conversely causes harm. True human beings do not do this, but that the whole world engages in such actions while unaware of their error is the third issue that people of old lamented in pain, wept, and sighed about (Zenseki 1744, pp. 5b-6a).

Zenseki follows this passage with a translation of Zhuhong's commentary, in which the translator spells out Chinese cultural references in simple terms. Zenseki fleshes out the story of Emperor Wu of the Liang, saying that he offered wheat dough instead of oxen and sheep and that people criticized him for not conducting the ancestral rituals properly and violating ritual propriety. He counters that having the right inner attitude toward the ancestors while making vegetarian offerings from the land and sea should meet the standards of ritual propriety. Zenseki also provides an explicit quotation from the Yijing in place of Zhuhong's oblique allusion to this classic so that even a reader without much background in Chinese history or the Chinese classics can understand the meaning. Despite these additions, Zenseki's vernacular rendition is far more similar to Zhuhong's original than was the case with Ryōi's Tale. A similar development toward more accurate translation also occurred in the case of vernacular editions of Zhuhong's Record of Self- 
Knowledge. This text appeared in several abridged editions over the course of the eighteenth century, and the first full and relatively accurate vernacular edition titled Zōho eshō waji kōga jichi roku (Illustrated record of self-knowledge in Japanese script) appeared approximately one hundred years later in 1800 (Figure 2).

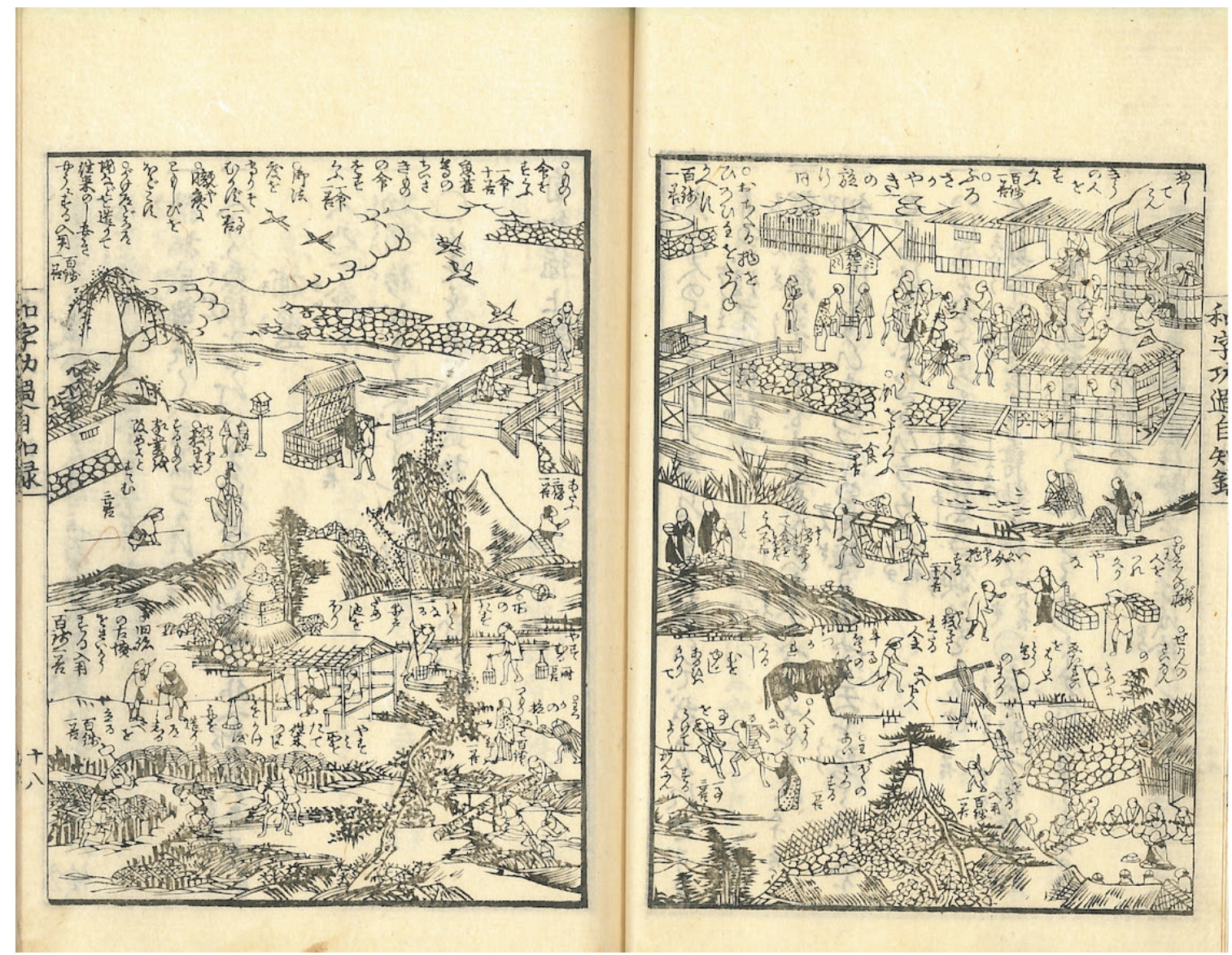

Figure 2. An illustration from Illustrated Record of Self-Knowledge in Japanese Script depicting people performing a variety of good deeds, such as releasing birds and turtles on a bridge and fish from baskets on the riverside. The caption on the top of the left page explains: "Rescuing animals counts as ten merits for one life; small animals such as sparrows and fish count as one merit for one life." (Original in author's collection.)

Enkyō's Commentary on the Tract on Refraining from Killing and on Releasing Life (1682) also makes various cultural, historical, and literary allusions explicit, but it does so by reproducing Zhuhong's text and adding extensive lexigraphic annotations in Sino-Japanese. Enkyō published several Buddhist texts around 1680, including two other lexigraphic commentaries: Kyōkai ritsugi sangyōshō (1679) on Daoxuan's (596-667) Jiaojie xinxue biqiu xinghu lïyi (Admonitions for the new student-monks to maintain discipline; T.1897) and Bonmōkyō kojaku onchi (1685) on the Silla Yogācāra cleric Taehyeon's Beommanggyeong gojeokgi (Exposition of the ancient teachings of the sūtra of Brahma's net; T. 1815). The latter commentary of Enkyō's includes a preface by "Ekū bhikṣu of Sumiyoshi Jizōin" (Enkyō 1685, pp. I.i.a-ii.b). This refers to Kaien Ekū (1622-1712), a high ranking Shingon cleric who also served as the abbot of Entsūji on Mt. Kōya and Jinbōji in Kii Province. ${ }^{4}$ Since Enkyō's name shared the character "en" with Kaien Ekū, he may well have been the latter's student. This suggests that Enkyō also belonged to the Shingon school and specialized in texts on the Buddhist precepts. Given Enkyō erudition, he may also have had some training in Confucian learning.

In his Commentary, Enkyō reproduced each section of Zhuhong's Tract, including both Zhuhong's main text and commentary, in Sino-Japanese, but he did not include 
Yinyuan's verses. Nonetheless, the Sino-Japanese markers in Enkyō's version followed the 1661 edition quite closely but were slightly more explicit about spelling out grammatical indicators and including more hints at reading the Chinese characters. For each section in Zhuhong's Tract, Enkyō provided extensive lexigraphic annotations that explained the meaning of individual words and listed citations from the relevant Chinese classics and Buddhist texts without providing any narrative or a cohesive argument. This suggests that Enkyō's commentary was written as a reference work for a literate audience, likely Buddhist clerics.

Enkyō's annotations are a bricolage of lexigraphic glosses from classical Chinese and Buddhist texts. They consist of lists of quotations and sometimes contain layers of annotations within annotations. For instance, his annotation on the above-mentioned passage on refraining from killing when making ancestral sacrifices begins with a gloss for the word "offer up sacrifice" from the first book of the Erya (Approaching elegance, 4th to 1st century BCE), followed by a gloss for "death anniversary" from the "Meaning of Sacrifice" chapter of the Record of Rites:

The saying that the superior man mourns all his life for his parents has reference to the recurrence of the day of their death. That he does not do his ordinary work on that day does not mean that it would be unpropitious to do so; it means that on that day his thoughts are occupied with them, and he does not dare to occupy himself as on other days with his private and personal affairs. (Translation adapted from Legge 1885, pp. 211-12)

Enkyō adds additional annotations on specific words within this passage from a commentary on the Record of Rites. He then follows up with a gloss for "day" from Approaching Elegance. He continues in this manner, offering glosses for individual words and longer phrases from classical Chinese literature and Buddhist texts, including the Xiaojing (Book of filial piety), the Avadāna (Ch. Piyu jing), Zhuhong's Jottings by a Bamboo Window, Zhang Yungu's Dabao zhen (Great treasure admonitions; ca. 626), Li Shan's Wenxuan zhu (Commentary on selections of refined literature; 628), and Muan Shanqing's Zuting shiyuan (Topics from the garden of the patriarchs; 1108) (Enkyō [1682] 1964, pp. 15a-b). In summary, Enkyō's text elucidated the literal meaning of Zhuhong's Tract but did not present a coherent narrative or engage his readership affectively.

Whereas Enkyō's work takes a lexigraphic approach to supplementing and clarifying Zhuhong's Tract, Dokuan's Anthology of Tracts on Refraining from Killing and Releasing Life (1692), also written in in Sino-Japanese, placed an abridged version of Zhuhong's Tract in the context of other Chinese Buddhist tracts and ritual texts on the topic of refraining from killing and releasing life that Dokuan excerpted from several different Ming collections. According to the preface Dokuan intended this anthology as a means to spread the ethic of refraining from killing and releasing life. He explained that living beings should be valued and treasured since there was nothing more valuable than life. Those who took the lives of living beings incurred their resentment while those who bestowed life upon them would receive their gratitude. To illustrate this point, he gave the example of a person who was promised gold and a large tract of land in exchange for their life and stressed that everyone would naturally choose their life over riches since life is infinitely more valuable. Therefore, Dokuan stated, taking one life was a great sin while releasing a single life led to great blessings. He added that he compiled this anthology comprising various tracts on refraining from killing and releasing life in order to spread a virtuous message of wisdom and benevolence, in hopes of changing the custom of killing and, instead, establishing the roots of benevolence and righteousness (Dokuan 1692, pp. i.a-iv.a). The Confucian overtones of Dokuan's preface are striking, particularly since Dokuan's text appeared during the Tsunayoshi's reign.

A contemporary of Enkyō's, Dokuan Genkō (1630-1698) was a Sōtō Zen cleric who had studied under the Chinese Linji monk Daozhe Chaoyuan (1630-1698) in Nagasaki and also interacted with other Chinese monks there. In this way, Dokuan developed some familiarity with late Ming and early Qing Buddhism. He particularly admired the late-Ming 
Chan masters Zhuhong and Yongjue Yuanxian (1578-1657) (Nagai 1995). Consequently, the centerpieces of his Anthology consist of an abridged version of Zhuhong's Tract and a tract by Yongjue, which Dokuan surrounds with a variety of other sources on the topic of refraining from killing and releasing life that were either compiled or reprinted during the Ming.

The Anthology comprises the following five parts and combines Buddhist, Confucian, and Daoist sources:

(1) Five tracts on refraining from killing, three of which were originally from Zongben's Pointing Directly to the Return to the Origin (X.61, no. 1156) but, along with Zhuhong's Tract on Refraining from Killing, were excerpted from Li Zhi's (1527-1602) Yinguo lu (Record of karma; Li 2010):

(a) "Patriarch Puan's [1115-1169] Tract on Refraining from Killing", which argued against blood sacrifices to divinities (abridged version from Li Zhi's Record of Karma).

(b) “Zen Master Foyin's [1032-1098] Tract on Refraining from Killing", which argued that all animals had Buddha nature, and, therefore, they should not be killed and eaten; instead, people should contemplate the Buddha and release life (from Li Zhi's Record of Karma).

(c) "Zen Master Zhenxie's [1089-1151] Tract on Refraining from Killing", which argued against killing animals to entertain guests as this would lead to retribution in hell; instead, people should contemplate the Buddha to be reborn on the highest level in the Western Pure Land (from Li Zhi's Record of Karma).

(d) "Zen Master Lianzhi [Zhuhong]'s Tract on Refraining from Killing", which argued against killing to mark life-cycle events, make a living, or worship the gods (abridged version from Li Zhi's Record of Karma).

(e) "Zen Master Yongjue's Tract on Refraining from Killing", which argued against killing and eating animals and promoted being compassionate and benevolent toward living beings (from Yongjue's Jingci yaoyu (The Essential sayings of Jingci [monastery]); reprinted in Japan in 1673; X.61, no. 1166).

(2) Five tracts on releasing life:

(a) "Eminent Monk Huiji of the Liang Dynasty's Tract on Releasing Life", which consisted of the biography of Huiji who begged for money for life releases and discouraged people from killing and eating animals (from Tiantai Master Ciyun Zunshi's (964-1032) Jinyuanji (Golden garden compendium; X.57, no. 950).

(b) "Zen Master Lianzhi [Zhuhong]'s Tract on Releasing Life", which argued that even insects sought to avoid death and provided short references to twentyeight karmic tales that illustrate the benefits of releasing life (abridged version from Yan's Record of Gaining Good Fortune; Yan n.d., pp. 8.28a-29a).

(c) "Zen Master Yongjue's Tract on Releasing Life", which promoted having compassion and releasing life because the Buddha loved all living beings and life releases; by contrast, killing caused fear and sorrow (from Yongjue Yuanxian's The Essential Sayings of Jingci; X.61, no. 1166).

(d) "Discourse on Promulgating Releasing Life", which encouraged releasing animals that were about to be killed and engaging in moral conduct to attain good fortune but warned against acts harming animals because those will lead to rebirth in the animal realm," by Chen Jiafu (1560-1611) (from Yan's Record of Gaining Good Fortune; Yan n.d., pp. 8.29a-32a).

(e) "Grand Master Ciyun's Gateway of Liberating Life", which comprised a liturgy for a life release (from Ciyun's Golden Garden Compendium; X.57, no. 950).

(3) Two biographies illustrating the ethic of refraining from killing and releasing life:

(a) Lu Fahe (d. 558), a Buddhist monk turned official who could ward off venomous insects and dangerous beasts, practiced life releases, and warned 
against the karmic retribution for killing (from Li Yanshou's History of the Northern Dynasties; Li 1639, pp. 89.77.15b-19a).

(b) Yelü Chucai (1190-1244), a Khitan statesman who was skilled at prognosticating from animal behavior and advised the Mongol conquerors to love life and dislike killing (from Vol. 33 of the biography section of the Song Lian's History of the Yuan; Song 1874, pp. 146.33.1a-3a, 9b-10a).

(4) Appendix:

(a) Four passages on life release ponds and on keeping fish from part 2, volume 12 of Zhu Mu's Gujin shiwen leiju (Antique and modern compendia, 1246; reprinted in the Ming in 1604; reprinted in Japan in 1666; Zhu 1666, pp. 34.6b10, 34.12b-13a):

(i) "Inscription of a Life Release Pond from the Tang" by Yan Zengqing (709-785)

(ii) "Record of the Life Release Pond of Guangde Division" by Lu Wuhuan (1125-1210)

(iii) "Record of Yong Ze Pavilion" by Hong Jinglu (1123-1202)

(iv) "Record of Caring for Fish" by Cheng Zhengshu (1033-1107)

(b) The third precept on not killing for food and extending benevolence and compassion to animals from the Tang-dynasty Daoist Xuhuang tianzun chuzhen shijie wen (Tract of the first true ten precepts of heavenly emperor $\mathrm{Xu} ; \mathrm{He}$ 1906-1917, pp. 223.54a-b).

This combination of texts allowed Dokuan to demonstrate that the ethic of refraining from killing and releasing life was supported by the Three Teachings of Buddhism, Confucianism, and Daoism. In parts one and two, Dokuan's focus on texts presented as having been composed by Zen masters highlighted the importance of life releases in Zen Buddhism, while at the same time also stressing the connection between life releases and pure-land practice. Parts three and four comprise sources about or by officials and scholars, as well as an excerpt from a Daoist text. The inclusion of Lu Fahe's and Yelü Chucai's biographies is striking in that Dokuan reproduced them in great detail, even down to the military campaigns in which $\mathrm{Lu}$ and Yelü were involved. These two biographies are an idiosyncratic choice, but they could have had special resonance for a late seventeenth-century audience given the context of Tsunayoshi's Laws of Compassion that sought to curb the violence of the warrior elite and instill benevolence in the populace.

While Dokuan included Zhuhong's Tract, he may not have consulted the original text directly but relied only on later Ming compendia that included abridged versions. In the first section on refraining from killing, Dokuan's primary source was Li Zhi's Record of Karma. This is supported by several indications. Even though the first three tracts on refraining from killing originally appear in Zongben's Pointing Directly to the Return to the Origin, the versions included in Dokuan's Anthology are identical to the abridged versions in Li Zhi's Record of Karma. Moreover, both Li Zhi's Record and Dokuan's Anthology omit "Patriarch Youtan's Tract on Refraining from Killing," which appears alongside Foyin's, Zhenxie's, and Puan's tracts in Zongben's work. The abridged version of Zhuhong's Tract on Refraining from Killing is also identical to the version that appears in Li Zhi's Record (Li 2010, pp. 89-93; X.61, no. 1156, 1.0448a04-0448c09).

To gain a sense of how Li Zhi's abridged version that Dokuan included in his Anthology differs from Zhuhong's original Tract, let us briefly examine in the passage on not offering blood sacrifice to the ancestors. For the sake of clarity, I have italicized the wording that is different from Zhuhong's original Tract:

Item: It is not appropriate to make sacrificial offerings to the ancestral forebears. On death anniversaries and the spring and autumn grave-side offerings, one should refrain from killing to provide blessings in the netherworld. Some say that Emperor Wu of the Liang replaced live animal sacrifice with dough, and they made him out to be an ignorant fool. Alas! If venerating the previous kings with bloody foods 
honors their mouths and stomachs, why is it that offering vegetarian feasts to the former kings causes them to be immediately born in heaven? To perform the yue sacrifice is superior to slaughtering an ox. If we are ready to alter received inclinations in the interest of clarifying instruction, then animal sacrifice should be seen as more unfilial still. The sages allowed this line of reasoning. Why must we cling to the idea of making blood sacrifices? (Li 2010, p. 94; Dokuan 1692, pp. 4a-b)

Li Zhi's version abridged and merged Zhuhong's main text and commentary. The first sentence was from the main text while the rest of the passage condensed the commentary section. The wording in Li Zhi's version exactly matches the version in Dokuan's Anthology, which is evidence that this was Dokuan's source rather than Zhuhong's original tract.

In the case of Zhuhong's Tract on Releasing Life, Dokuan did not rely on Zhuhong's original Tract either. Dokuan included an abridged version of Zhuhong's Tract on Releasing Life; however, this version was excerpted from Yan Maoyou's Record of Gaining Good Fortune rather than Li Zhi's Record, which was abridged differently. Moreover, Dokuan also included Chen Jiafu's "Discourse on Promulgating Releasing Life" from the Record of Gaining Good Fortune in this section, another indication that Yan's compendium was Dokuan's source. The abridged version of Zhuhong's Tract on Releasing Life was extremely truncated and would only make sense to reader already familiar with contents of the original Tract because it omitted Zhuhong's commentary sections and only included his main text. In case of the karmic tales, the abridged version essentially just gave the titles of the stories rather than the tales themselves (Yan n.d., pp. 8.28a-32a). Despite his admiration for Zhuhong, Dokuan's engagement with Zhuhong's Tract was not extensive, a point that has also been made by Nagai Masashi in terms of Dokuan's familiarity with the breadth of Zhuhong's works in general (Nagai 1995, p. 91). Nonetheless, by including the abridged versions of Zhuhong's Tract, Dokuan was following literary conventions of Ming compendia that spread Zhuhong's work in a similar manner.

\section{Vernacular Tracts on Refraining from Killing and Releasing Life after $\mathbf{1 7 5 0}$}

From the mid-eighteenth century onward, the ethic of refraining from killing and releasing life became more widespread and diffuse. Japanese Buddhist clerics promoting life releases no longer sought to transmit Zhuhong's Tract in full or even an abridged form but embedded short excepts in their own vernacular tracts and used his Tract as a resource for didactic tales. They were inspired in content and form by Ming texts but created a rich original repertoire on the topic. They drew on a wide range of Chinese and Japanese compendia, morality books, and contemporaneous eye-witness accounts to convey the ethic of refraining from killing and releasing life to a broad Japanese audience. Eventually, several of these texts-Jishū's Hōjo kudoku shū (Compendium on the merit of life releases, 1783), Tainin's Hōjō tebiki gusa (Guide to life releases, 1784), and Junshō's Hōjō yorokobi gusa (Jottings on the joys of life releases, 1816)_-became as influential as Zhuhong's Tract. By then, life releases were strongly associated with the generation of posthumous merit for the ancestors.

Before discussing how texts from the late eighteenth and nineteenth century adapted Zhuhong's Tract, I would like to introduce the most important authors and their tracts to illustrate the cultural milieu in which these texts emerged. Like the earlier Buddhist clerics promoting Zhuhong's ethic of refraining from killing and releasing life, many of these eighteenth- and nineteenth-century Buddhist clerics were Sinophiles, but in contrast to their predecessors, they do not seem to have had any direct exposure to Chinese Ōbaku clerics. Instead, they were active in intellectual circles that engaged in acculturated forms of Chinese learning, and they were all invested in the observance of the Buddhist precepts and in public morality.

The first group of authors is connected to Jishū's Compendium on the Merit of Life Releases. Rokunyo Jishū (1734-1801) was a Tendai scholar monk and a prolific author of Chinese poetry in the Song style. He was born in Hachiman village in Ōmi Province as the son of a doctor. He studied Confucianism as child but became ordained under the Tendai 
high priest Kankoku on Mt. Hiei in 1744. He followed Kankoku to Musashi Province two years later. As Jishū moved back and forth between eastern and western Japan throughout his life, he continued to associate with Confucian scholars and poets, including the Kyotobased writer Ban Kōkei (1733-1806). In 1757, Jishū moved to Kyoto and entered Zenkōji on Mt. Hiei before returning to eastern Japan to enter Kan'eiji's subtemple Shinryōin in 1766. He was banished from Kan'eiji due to a sectarian dispute in 1767 and returned to Kyoto in the following year. After being reinstated in 1772, Jishū reentered Kan'eiji in 1775. Around the time that his mother died in 1781, he returned to Kyoto with his mentor, the former abbot of Kan'eiji. It was during this period that he compiled the Compendium for his mother's repose in the afterlife, as he explained in the preface to the work. The Compendium was published by Kan'eiji in 1783 (Imazeki 2015, pp. 122-26; Fujikawa 2012, pp. 11-12; Kurokawa 1990, pp. 420-21, Jishū 1783, pp. I.iii.b-iv.a).

A seminal and expansive vernacular compilation, Jishū's Compendium comprises several introductory and closing chapters in which Jishū synthesizes Zhuhong's thought on life releases. These chapters had titles such as "Compassion Should Be the Fundamental Attitude toward Life Releases", "The Brahma Net Sutra Promotes Life Releases", "People Who Conduct Life Releases Should Not Kill", "People Should Strive to Release Lives Daily", "A Liturgy for Life Releases", "The Gods Dislike Killing and Rejoice at Releasing Life", "People Practicing Pure Deeds Should Also Practice Life Releases", "Rewards and Retribution for Good and Evil Cut across Past, Present, and Future", and "[Zhuhong's] Dedications of Merit for Refraining from Killing and Releasing Life." In addition, the Compendium included approximately 180 didactic tales that illustrated the ethic of refraining from killing and releasing life.

Jishū's collection played a central role in popularizing the teachings of Zhuhong's Tract in Japan by extending strategies already employed by Asai Ryōi, but Jishū's work had far greater circulation and reach than Ryōi's. Jishū's Compendium became an important tool for sermonizing. It was reprinted at an unspecified later date under the title Kange hitsudoku seppō innen shū (Must-read compendium for sermonizing on karma), which claimed on its title page (Figure 3):

This book collects true tales from several ten thousand volumes of books and is the best book for sermonizing to old and young, men and women. And it is a truly useful compendium for sermonizing on accumulating secret merit by performing charitable good deeds and attaining longevity, descendants, and business success. It is an outstanding book that must be placed on the right side next to the seat of a sermonizing instructor. (Jishū n.d.)

Jishū's Compendium also served as a crucial resource for several later Japanese tracts on life releases, including the Shingon cleric Kanjun's Clarification of Life Releases in the Three Teachings (1803), Kaisetsu hōjō mon (Tract on admonishing against killing and on releasing life; 1836) by an anonymous Tendai ācārya (J. ajari) from Kuramadera near Kyoto, and the Shingon cleric Taikyo's Record of the Hidden Aid of Life Releases (1898). Kanjun's Clarification reproduced ten tales from Jishū's Compendium while the ācārya's Tract on Admonishing reproduced twenty tales and summarized the introductory chapters. Taikyō's Record reproduced twenty-five tales and material from the introductory and closing chapters of Jishū's Compendium. In addition, Jishū's collection was cited by several other authors in nineteenth-century pamphlets on life releases.

As for the authors of the texts influenced by Jishū's Compendium, we know relatively little about the anonymous Tendai ācārya, Kanjun, and Taikyo or the production of their tracts other than what the texts directly tell us. According to its colophon, the Tract on Admonishing against Killing and on Releasing Life was printed by a Tendai cleric by the name of Kōshin, the abbot of Yōgyokuin in Shitaya in Edo, as a form of charity after he obtained the text; the text itself was composed by an anonymous ācārya at Mt. Kurama, a Tendai temple north of Kyoto (Figure 4). The tract contains several first-person references to this ācārya who was active mostly in the Kyoto area but also had connections through sectarian networks to clerics in Edo and Musashi Province and may have been an approximate 
contemporary of Jishū's (Kaisetsu hōjō mon 1836, pp. 17a-20a). We also learn that the ācārya had practiced regular life releases since his youth: when he was young, he suffered from a distended stomach, which the local doctor told him was difficult to cure. He therefore bought three soft-shell turtles, conducted a ritual, told the turtles that he wanted to be cured from his illness, and released them. He started recuperating day by day and was soon cured. In the twenty years since then, he acquired two or three turtles every year and transferred merit to them before releasing them (Kaisetsu hōjo mon 1836, p. 18b). The ācārya's Tract on Admonishing consists of three parts titled "The Karma of Killing and the Six Upoṣadha Days", "Short Liturgy for Life Releases", and "Retribution for Killing." The colophon explains that Tract on Admonishing comprises selections from Jishū's Compendium supplemented with Japanese stories so that the work could serve to admonish ignorant children (Kaisetsu hōjō mon 1836, p. 20b).

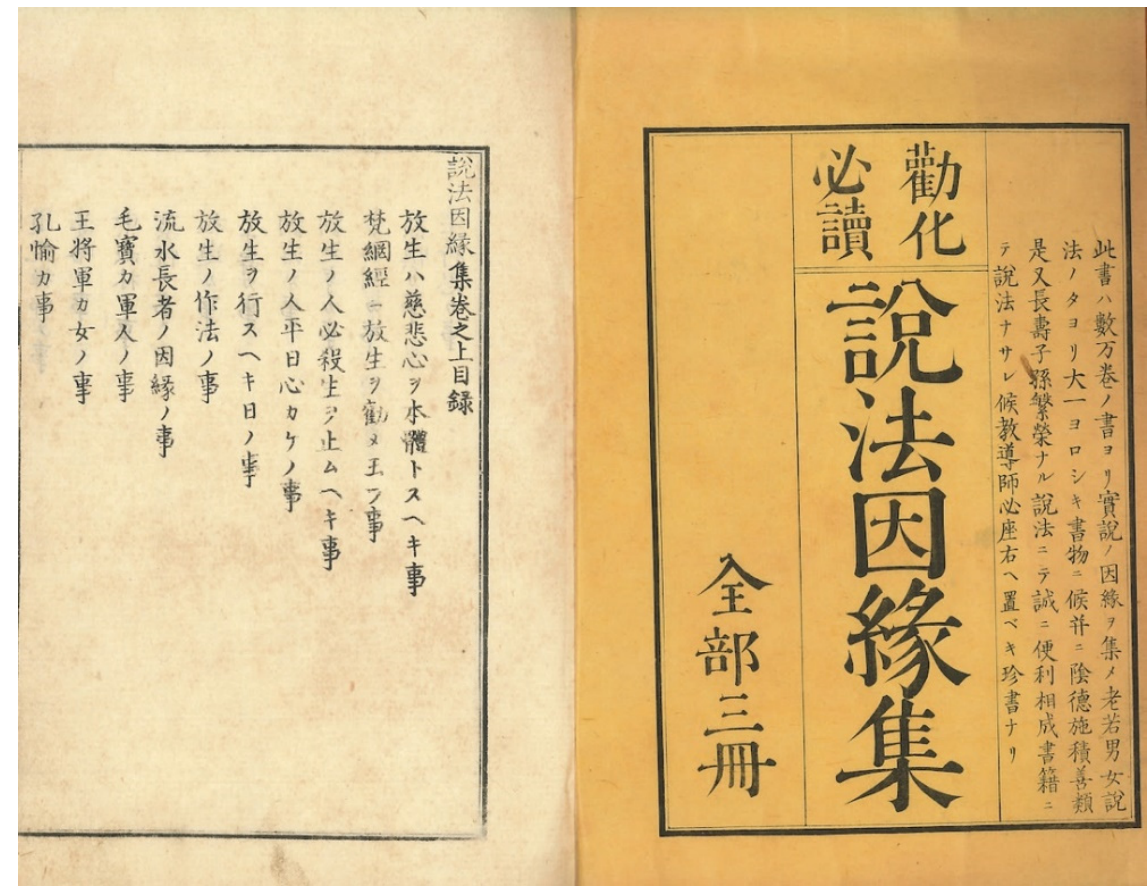

Figure 3. The title page and table of contents of the first volume of a Jishū's Compendium on the Merit of Life Releases reprinted under the new title, Must-Read Compendium for Sermonizing on Karma. The original title was replaced with the reprint's; otherwise, the printing blocks are identical with the original's. (Original in author's collection.)

Kanjun, the author of the four-volume, illustrated Clarification of Life Releases in the Three Teachings, was an approximate contemporary of Jishū's and was clearly familiar with Zhuhong's Tract and Jishū's Compendium (Figure 5). He was a Shingon cleric from Tajima Province who also had connections to Kyoto, Osaka, and Kii Province. The Clarification's two prefaces were composed, respectively, by Kaishi, a cleric at the Shingon temple Sennyūji in Kyoto, and the above-mentioned Ban Kōkei, who was also acquainted with Jishū. Like Jishū, Kanjun was well versed in Chinese literature and readily cited such texts as the Analects, Mencius, Great Learning, Records of the Grand Historian, and Book of the Later Han in addition to Zhuhong's Tract and Jishū's Compendium. As an ardent proponent of Ryōbu Shūgō Shintō, Kanjun was deeply invested in demonstrating that the Three TeachingsBuddhism, Shinto, and Confucianism-agreed on the issue of refraining from killing and releasing life, but he also asserted that only Buddhism offered the ritual means to offer humans and animals posthumous salvation through merit transfer (Kanjun 1803, p. IV.18a). 


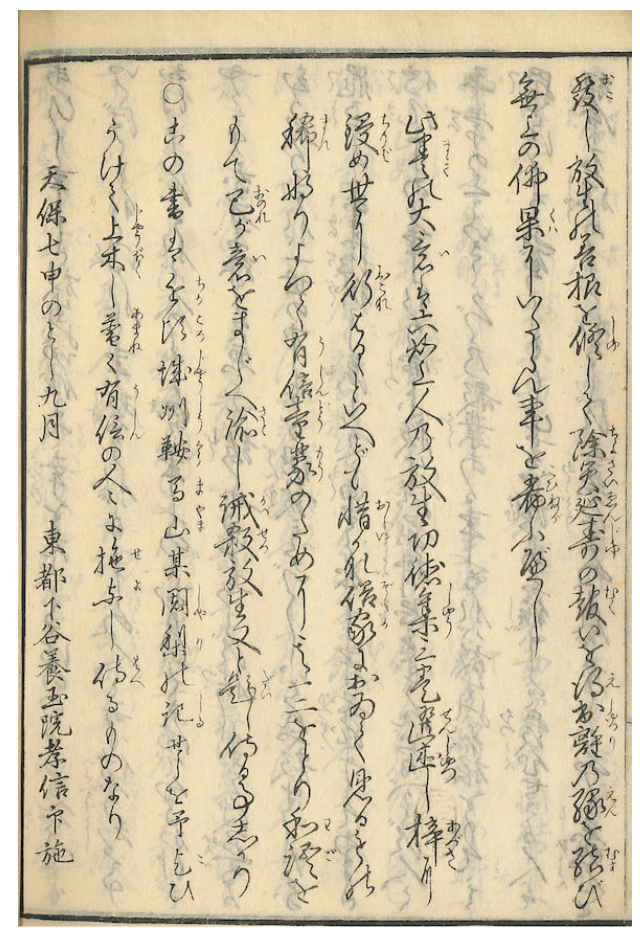

Figure 4. Colophon of the Tendai ācārya's Tract on Admonishing against Killing and Releasing Life describing the provenance and purpose of the text. It states that the text contains twenty entries from Jishū's Compendium and that the text was written by an anonymous ācārya from Mt. Kurama. (Original in author's collection.)

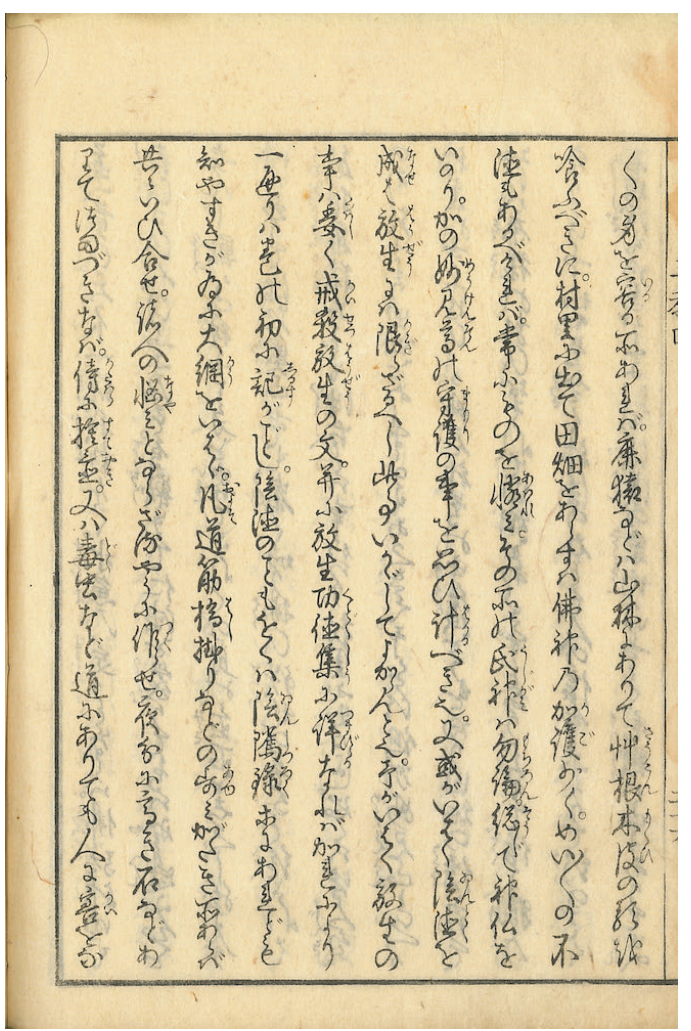

Figure 5. This page from volume 4 of Kanjun's Clarification of Life Releases in the Three Teachings mentions Zhuhong's Tract on Refraining from Killing and on Releasing Life and Jishū's Compendium on the Merit of Life Releases as good resources on life releases and Yuan Liaofan's Record of Hidden Recompense as a good resource on secret merit. (Original in author's collection.) 
Taikyo, the compiler of Record of the Hidden Aid of Life Releases, was a Shingon cleric from western Kyoto who appears to have had sectarian connections to Osaka and the Tokushima Domain in Awa Province in Shikoku. The opening verse of the volume was produced by Eigon (1814-1900), a high-ranking Shingon cleric who had served as the monzeki of Ninnaji and abbot of Tōji in Kyoto. Despite belonging to a different denomination, Taikyo borrowed liberally from the Tendai cleric Jishū's Compendium without explicitly acknowledging his indebtedness. Taikyo emended some of the contents to adapt it his own sectarian interests; for instance, he included references to Kōbō Daishi and a few doctrinal idiosyncrasies of the Shingon school. In addition to the material from the Compendium, Taikyo also drew on the Jōdo cleric Nen'a Junshō's Jottings on the Joys of Life Releases (1816) and additional tales from the Chinese compendia that served as resources for Jishū. In contrast to the earlier authors, Taikyo compiled his tract in the Meiji period, an age of rapid change, and used karmic tales about life releases to refute modernist ideas that were emerging due to Western influences such as the notion held by "the proponents of modernization" that animals had no spirit and thus were different from humans (Taikyo 1898, p. 50). ${ }^{5}$

The second group of authors comprises Tainin Myōryū and Nen'a Junshō, who authored influential tracts during the late Edo period: Guide to Life Releases and Jottings on the Joys of Life Releases, respectively. Both texts were composed in response to requests from lay devotees who sought instruction on the topic of life releases, suggesting that by this period the charitable practice of life releases was popular among the laity. These two texts had considerable influence on lay associations dedicated to the practice and promotion of life releases in the mid- to late-nineteenth century.

A generation older than Jishū, Tainin (1705-1786) was a Shingon cleric from Mino Province who served as the abbot of Yagotosan Kōshōji in Owari Province for most of his life. Having specialized in the study of the Buddhist precepts and pure land doctrine, he was the prolific author of a wide variety of texts and had close interactions with clerics of the Pure Land and Zen schools (Kawaguchi 1989). In 1782, he was approached by a lay devotee called Teihaku who sought clarification about life releases after he had read a story about the eighth-century Chan Master Deng Yinfeng giving up hunting because the latter witnessed a monkey mother die from grief over the death of her baby monkey. In response to Teihaku's questions, Tainin authored a tract titled Hōjō shinansha (A vehicle pointing south on life releases, 1783) so that the layman could share it with his likeminded friends. Tainin then expanded his tract from six to ten topics and published the longer version in 1784 under the new title Guide to Life Releases. Reprints of the Guide appeared in 1841, 1853, 1887, and 1898 (Kawaguchi 1995). Tainin's tract was written in a question-and-answer format that resembled Zongben's Pointing Directly to the Return to the Origin, and the title of A Vehicle Pointing South on Life Releases may be a subtle hint at the connection.

Nen'a Junshō was the abbot of the Pure Land temple Seiganji in Kyoto. He was connected to Pure Land networks: the 1816 edition of his Jottings was published simultaneously by two shops that were located near the large Pure Land temples Chion'in in Kyoto and Zōjōji in Edo, respectively. Junshō's devotees included Pure Land monastics in the Kyoto area, and he must have had particularly strong ties with the Pure Land community in Ôtsu in Ömi Province. The 1816 edition includes a preface by the Pure Land cleric Entatsu from Imashikadera in Ōtsu. Junshō also indicates that he wrote this text after the layman Tetsuō from Ōtsu came to see him in 1812 and asked him to compose an essay that extolled the positive karmic roots cultivated through life releases so that the layman and his friends could spread the practice among future generations. This layman then appears to have published the 1812 edition (Junshō 1812, pp. 1a, 15a; Junshō 1816, p. 1a).

Junshō first published Jottings in 1812, and a second, expanded version appeared in 1816 that was widely circulated and cited in several later tracts on the topic of life releases. The shorter 1812 version included more material from Zhuhong's Tract and explicitly identified both Zhuhong and Tainin as sources. The 1816 version redacted the original tract and added seven chapters about (1) pious lay devotees of Junshō's who 
practiced life releases and (2) wholesome moral conduct in general. The 1816 version was the more influential of the two editions. For instance, not only did Taikyo's Record excerpt two of its chapters, but also it was the basis for a painting by Kanō Eitai (d. 1842) that showed Junshō officiating over a life release and featured several human and animal characters that appeared in his text. The painting had a Chinese inscription dated 1829 by the Rinzai cleric Shinjō from Kenchōji in Kamakura who had composed the verse upon the request from Shōzan, a cleric from Tōfukuji, a Rinzai temple not very far from Junshō's temple (Ambros 2019). Along with Tainin's Guide, Junshō's Jottings was later referenced in publications by nineteenth-century charitable societies dedicated to life releases.

\section{Synthesizing and Assimilating Zhuhong's Ethic of Refraining from Killing and Releasing Life}

Late-Edo-period tracts on refraining from killing and releasing life were influenced by Zhuhong's Tract, but references to Zhuhong were more diffuse than in the works of the early Edo period. Jishū's Compendium is an early and illustrative example. Jishū used two strategies to adapt and amplify Zhuhong's message: (1) his Compendium contained a large selection of didactic tales that illustrated Zhuhong's message through graphic examples, including twenty tales excerpted from Zhuhong's Tract, and (2) Jishū embedded quotes from and references to Zhuhong's Tract in his commentary, but often the references are challenging to identify because they are highly synthetic. Among his opening and closing chapters, the final chapter on Zhuhong's dedication of merit is the only one that exclusively cites, transcribes, and comments on a portion of Zhuhong's text other than the karmic tales.

Tales culled from Tract on Refraining from Killing and on Releasing Life are most easily identifiable as adaptations from Zhuhong's text in late-Edo-period tracts. Zhuhong relied on karmic tales in order to convince readers that his claims were true and to elicit a strong affective response in his readers. Zhuhong stated explicitly that he deployed tales that dealt with either chronologically distant or recent matters as proof for the veracity of the ethic of refraining from killing and releasing life (J.32, no. B277, 11.0760b25-26). In other words, past and present evidence demonstrated that the ethic of releasing life cut across religious boundaries between the Three Teachings and transcended time. These karmic tales had a decisive effect on Zhuhong's readers. Jennifer Eichman argues that the tales in Zhuhong's Tract provided a way for contemporary readers to understand the workings of karma in their own daily lives. They accepted the tales as empirical proof for the truth of his argument against killing and for releasing life, and they were convinced by the exigency of engaging in morally upright behavior in order to avoid karmic retribution (Eichman 2016, p. 122). I would like to extend Eichman's interpretation to suggest that Zhuhong employed visceral karmic tales in order to trigger compassion in his readers through affect. That is, he generated compassion with animals through graphic karmic tales that touched readers emotions by provoking horror, disgust, fear, and joy and illustrated the karmic physical entanglements between humans and animals that readers could then use to give meaning to their actual life releases.

Late-Edo-period Buddhist clerics likewise included a large number of karmic tales in their tracts order to make them affectively engaging, and they usually drew on Zhuhong and other Chinese sources rather than medieval Japanese tale collections. As Ishiguro Kichijirō has shown, Japan had its own rich didactic-tale literature on refraining from killing that was scattered across various medieval collections (Ishiguro 2006, 2007, 2008). The early modern Sinophile proponents of life releases, however, largely ignored these resources. For instance, the 180 karmic tales in Jishū's Compendium included twenty tales culled from Zhuhong's Tract on Releasing Life and approximately 150 stories were borrowed from Tang, Song, and Ming dynasty anomaly accounts and karmic tale collections. ${ }^{6}$ Only a handful of stories were from two medieval Japanese sources: Mujū Ichien's Shasekish $\bar{u}$ (Compendium of sand and pebbles, 1283) and Kokan Shiren's Genkō shakusho (Genkō era Buddhist history, 1322). That Jishū favored Chinese source materials is indicative of his literary interests as well as the strong Ming Buddhist influence on early modern 
discourses about life releases. Tracts published after Jishū's were more likely to include Japanese tales, but these were usually set in the recent past rather than the medieval period: they were either eyewitness accounts from the authors' circle of acquaintances or excerpted from early modern karmic tale collections such as Rentai'a Shingon kōshaku shū (Shingon crystal compendium, 1692), Yuia Shōkin's Shinsen hosshinden (Newly compiled chronicle of arousing the aspiration for enlightenment, 1736), and Issōken Roshuku's Kindai kenbun zen'aku goppō innen shū (Compendium of recent observations of good and evil karmic recompense, 1788). By including both distant Chinese tales and recent Japanese accounts, the Japanese compilers imitated Zhuhong's strategy of giving evidence from distant historical sources and eye-witness accounts set in the recent past.

Late-Edo-period tracts adapted materials from a variety of Chinese and Japanese sources, and Zhuhong's Tract served as an important source for karmic tales that allowed readers to grasp the ethic of refraining from killing and releasing life affectively. The three most frequently included tales from Zhuhong's Tract were related to the extension of life spans as a reward for life releases: the young śramana whose life is extended after he saves ants from drowning, the kitchen maid of the Cheng family whose life is saved during an epidemic by a soft-shell turtle that she had saved and released earlier, and the wine brewer whose death penalty is revoked after the flies he had saved earlier interceded on his behalf. In China, longevity had been a primary benefit of life releases from at least the Song into the Ming and Qing dynasties (Eichman 2016, p. 193). This remained an important benefit associated with life releases in Japan as well, even though merit for deceased family members became the primary motivation eventually.

By the nineteenth century, however, Japanese clerics promoting life releases were less and less likely to excerpt a large number of karmic tales from Zhuhong's Tract. The following chart indicates the number of tales from Zhuhong's Tract included in various Edo-period tracts on life releases (Table 1):

Table 1. Tales from Zhuhong's Tract on Releasing Life Included in Japanese Texts on Life Releases.

\begin{tabular}{|c|c|}
\hline Author and Title of the Text & Number of Tales from Zhuhong's Tract on Releasing Life \\
\hline Asai Ryōi, Kaisetsu hōjō monogatari (1664) & 14 \\
\hline Enkyō, Kaisetsu hōjō mon sange (1682) & 28 \\
\hline Dokuan, Kaisetsu hōjō mon hen (1692) & 28 \\
\hline Zenseki, Kaisetsu hōjō mon wage (1744) & 28 \\
\hline Jishū, Hōjō kudoku shū (1783) & 20 \\
\hline Tainin, Hōjō shinansha (1783)/Hōjō tebiki gusa (1784) & $3 / 14$ \\
\hline Kanjun, Sankyō hōjō benwaku (1803) & 5 \\
\hline Zaizen, Hōjō hōō shū (1806) & 9 \\
\hline Junshō, Hōjō yorokobi gusa (1812/1816) & $11 / 7$ \\
\hline Tendai ācārya, Kaisetsu hōjō mon (1836) & 3 (via Hōjō kudoku shū) \\
\hline Taikyo, Hōjō meikan roku (1898) & 2 (via Hōjō kudoku shū $)$ \\
\hline
\end{tabular}

As this chart shows, collections compiled until the late-eighteenth century were more likely to borrow heavily from Zhuhong's Tract, but the number of tales declined through the late-eighteenth and nineteenth centuries, and often the references became quite brief as the period progressed. One exception from the tendency of abbreviation is Kanjun's Clarification, which features only five tales from Zhuhong's collection but reproduces each tale in great detail. As exemplified by the tale of the kitchen maid of the Cheng family, cited at the beginning of this essay, Kanjun fleshed out the characters' emotions to heighten the affective appeal of the tales (Kanjun 1803, pp. II.1a-1b).

Since Zhuhong's ethic of refraining from killing and releasing life had become highly assimilated by the late eighteenth century, it is challenging to pinpoint borrowings from Zhuhong's Tract besides karmic tales. To illustrate the synthetic approach of late-Edoperiod tracts, I trace how the texts incorporated the above-mentioned passage about the veneration of ancestors. By the late Edo period, the temple parishioner system had become 
well established, and Buddhist funeral and memorial rituals had become the norm. These rituals did not include blood sacrifices. This dissonance had already led Asai Ryōi to change his rendition of this passage from Zhuhong's Tract. Similarly, most late-Edo-period tracts did not address the issue of ancestral sacrifices raised by Zhuhong but rather recommended the performance of life releases on memorial days to generate merit for the deceased, as well as for the celebrations of other life-cycle events. For instance, the Tendai ācārya's Tract on Admonishing against Killing and on Releasing Life argued against serving fish and fowl for birthday, birth, and wedding celebrations, at banquets, and as offerings to the deities. This list reiterated most of the occasions mentioned in Zhuhong's Tract but noticeably omitted ancestral sacrifices. Instead, the ācārya stated that people should conduct life releases on such celebratory occasions and that they should not assume that life releases should only be conducted in conjunction with funeral and memorial rituals (Kaisetsu hojō mon 1836, pp. 2a-3a). In other words, life releases were strongly associated with generating posthumous merit in conjunction with Buddhist death rituals.

Again, Kanjun's Clarification is an exception to this trend. Kanjun admonished people not to serve meat during Confucian ancestral rites, and he seemed to be alluding to Chinese customs because oxen and sheep were not commonly on the menu in early modern Japan:

And that people unscrupulously kill oxen, sheep, fish, and birds during ancestral rites in Confucian families and also at every-day banquets should be called a selfish convenience. It is said that in China, King Tang of the Shang went out into the fields, saw that a hunter had hung nets on four sides and took pity that all lives would be captured. He made the hunter take down the nets on three sides and leave only one side up so that those that wanted to run to the left could go to the left and those that wanted to climb up could climb up. This is showing benevolence even to birds and beasts. Even when people nowadays look at Confucian texts, it is not conclusively settled. They serve the lord of the country and admonish him to be benevolent, but there are few who carry out benevolent rule. (Kanjun 1803, p. I.14a)

In this passage, Kanjun made an oblique reference to Zhuhong's admonition not to offer meat at ancestral rites or serve meat dishes to guests in Tract on Refraining from Killing and added the story of King Tang (1675-1646 BCE), the first sovereign of the Shang, from Zhuhong's Tract on Releasing Life to illustrate his point about the need for extending benevolence to animals. In the passages that follow, Kanjun adapted Zhuhong's admonition not to serve meat on celebratory occasions to the Japanese context, as he stressed notions of death pollution: he emphasized that the divinities disliked the impurity of meat offerings and warned against serving fish and fowl at weddings since this would invite resentment from the parents and children of the fish and birds. He also added that people should not serve fish and fowl on New Year's Day because people avoided writing the character for "four" since it was homophonous with the character for "death." Eating fish and fowl would be like eating the character for death on that day (Kanjun 1803, pp. IV.18a-b).

Jishū's Compendium is more representative of other late-Edo-period tracts than Kanjun's Clarification in regard to the connection between life releases and ancestral rites. Jishū did not discuss the issue of making blood sacrifices to the ancestors but rather recommended the performance of life releases for life-cycle events and on other special days associated with the attainment of longevity, as well as on death anniversaries, which were conducive to generating posthumous merit. In the chapter titled "Days on Which to Perform Life Releases", Jishū argued that the wealthy should practice life releases every day while those with fewer resources could do so once a year. In addition, he recommended the following days as being especially suitable for life releases: the monthly six or ten uposadha days on which the Four Heavenly Kings monitor human behavior and determine human lifespans as a reward or punishment. ${ }^{7}$ In addition, life releases should be practiced on Buddhist holidays: the day the Buddha attained nirvana, the Buddha's birthday, and the Festival of the Dead on the fifteenth day of the seventh month. Jishū also recommended conducting life releases for personal life-cycle observances such as the death anniversaries 
of one's parents, Buddhist teachers, siblings, and friends in order to pray for their repose in the afterlife. One should release living beings and abstain from killing on one's own and one's parents' birthdays, as well as when children were born to ensure their longevity since these were the days on which life began. On days when one venerated the ancestors, since the ancestors delighted in seeing their descendants multiply, one should conduct life releases because this increased the population of living beings. On wedding days, since this was the beginning of human life, one should release living beings and refrain from killing. When entertaining guests on auspicious days and when viewing blossoms, one should refrain from killing animals because it would not agree with the cheerful atmosphere of the occasion. Life releases were also recommended when praying for recovery from illness or for other wishes. Jishū closed with the comment: "I've jotted down the above-mentioned points in summary of Great Teacher Yunqi [Zhuhong]'s Tract on Refraining from Killing" (Jishū 1783, pp. I.21a-22b). Indeed, this section rephrased Zhuhong's injunctions in Tract on Refraining from Killing against killing and consuming meat during life-cycle events and other celebratory occasions by blending them with Zhuhong's recommendation in the Tract on Releasing Life to conduct life releases on the six uposadha days because the heavenly bureaucracy monitors human conducted on these days. Jishū thereby shifted the focus from ancestral sacrifices to life releases.

Several texts published after Jishū's Compendium reiterated these recommendations, such as the instructions about releasing animals on the six upoșadha days. For example, the Tendai ācārya's Tract on Admonishing contained a section that summarized Jishū's explanation of the six uposadha days and recommended conducting life releases on these days. The ācārya added:

In addition to the six upoșadha days, if you conduct life releases on days when you venerate the ancestors or your parents or when you have a wish, the deceased who has fallen into the three evil paths can escape the suffering that results from the karma of their sins, be reborn in a heaven or pure land, and attain happiness thanks to the merit generated by the life release. Do not doubt this in the least! (Kaisetsu hōjō mon 1836, p. 9b)

The ācārya's comments highlighted the strong connection between life releases and the generation of posthumous merit for the beneficiary's good rebirth.

Similarly, Taikyo's Record repeated Jishū's instructions regarding the six upoșadha days and Buddhist holidays, but Taikyo also added a few details that reflected the sectarian interests of the Shingon school to which he belonged and time period in which he lived. Whereas Jishū had differentiated between the financial capabilities of the sponsors, Taikyo distinguished between three levels of commitment to life release practices, which seems to imply that more frequent life releases had greater merit rather than being only a reflection of the greater economic means of the sponsor. Those at the highest level conducted life releases every day. Those at the medium level conducted life releases on the six uposadha days. Additionally, those at the lowest level conducted life releases once a year on the fifteenth day of August, the same day as the Iwashimizu Hachiman life release. Then, Taikyo listed several extraordinary occasions that were largely identical to the life-cycle celebrations listed by Jishū, but he also added the monthly and annual memorial days for Kōbō Daishi, the founder of the Shingon school in Japan. In addition, since his Record dateed from the Meiji period, Taikyo included several modern imperial festivals such as Shihōhai (January 1) and Genshisai (January 3) (Taikyo 1898, pp. 3-8).

By contrast, neither Tainin's Guide nor Junshō's Jottings discussed the full range of occasions on which devotees should conduct life releases, but both mentioned that life releases were conducted in conjunction with memorial rites. Tainin's Guide opened with a question about the origin of life releases from a devotee who had witnessed the custom of buying eels and loaches at the market and releasing them to generate merit for the ancestors. In the context of another question, the devotee had heard that refraining from killing and releasing life was supposed to generate merit for the practitioners themselves and asked Tainin to explain how life releases make merit for a deceased person. Tainin 
responded that releasing life generated great benefit similar to rescuing a starving person or someone caught up in a fight. He argued that such actions generated merit because even though humans and beasts were different, they were also the same in that they both valued life. Therefore, both saving one eel or saving a human being generated merit, and saving many lives generated even more merit. He also noted that in the past, the imperial court would give rice to the poor, pardon criminals, and conduct life releases when sponsoring Buddhist services. These acts all had the same meaning. He pointed out that since the precept of not killing was the first among the five, eight, or ten precepts, releasing life was the greatest good deed that saved both oneself and others equally, and brought salvation to both the animals and the spirit of the deceased by means of the merit transfer (Tainin 1784, pp. 1a, 7b-8a). According to Kawaguchi Kōfū, these are all indications that by the late Edo period when Tainin was active, it had become a widespread practice to release animals to generate merit for the ancestors (Kawaguchi 1995, p. 608).

The connection between life releases and generating merit for deceased family members is also apparent in Junshō's Jottings. Junshō suggested that devotees should conduct life releases to generate posthumous merit for their parents. Giving us clues how life releases were embedded in daily religious practices, the text recommended that devotees place an offertory box next to their Buddhist altar where the ancestors were venerated at home since this was a location where people would frequently pass by. Each time that people approached the box, they should place two or three copper coins in it to save money for life releases that could be conducted monthly, on death anniversaries of their parents or siblings, or spontaneously to save a living being. Moreover, according to the colophon, the merit of printing of the 1812 version was dedicated posthumously to two layman, one laywoman, and the ancestors of the donor (Figure $6 a, b$ ). This is evidence that even the printing of a text on life releases was believed to generate merit for the deceased (Junshō 1812, pp. 15a, Appendix 1b, 6a; Junshō 1816, p. 36b). People also pooled their resources to sponsor life releases and generate merit for their dead relatives. A pamphlet titled $H \bar{o} j \bar{o}$ kanjin roku (Record of promoting life releases), which recommends Junshō's Jottings as a resource, was published in 1851 by a society dedicated to conducting monthly life releases of 10,000 fish and birds for the repose of the sponsors' ancestors (Gyokusui [1851] 2013, pp. 204-6).

Despite the strong emphasis on posthumous merit, however, this was not the only benefit associated with life releases, which were also said to generate vital benefits for the living members of the family. In his Tract, Zhuhong promised karmic rewards to all those who conducted life releases: good fortune, healing from illness, protection from disasters, rebirth in heaven, and the attainment of the Way (J.32, no. B277, 11.0760b20-21). In a short piece titled "Fangsheng dushuo" (Explanation of the life release chart) included among his Posthumous Papers, he spells out the vital benefits of life releases:

Releasing life enables one to escape the three disasters [of fire, water, wind];

Releasing life enables one to be free from the "nine kinds of untimely deaths (jiuheng)."

\section{Releasing life enables one to live long;}

Releasing life enables one to rise high in an official career;

Releasing life enables one to have many children;

Releasing life enables one to have a prosperous household.

Releasing life dispels anxieties and worries;

Releasing life reduces sickness and pain. (Translation in Yü [1981] 2020, p. 86; J.33, no. B277, 21.154b15-18)

For Zhuhong and his followers, life releases were sure to bring blessings to the lives and livelihoods of devotees. 


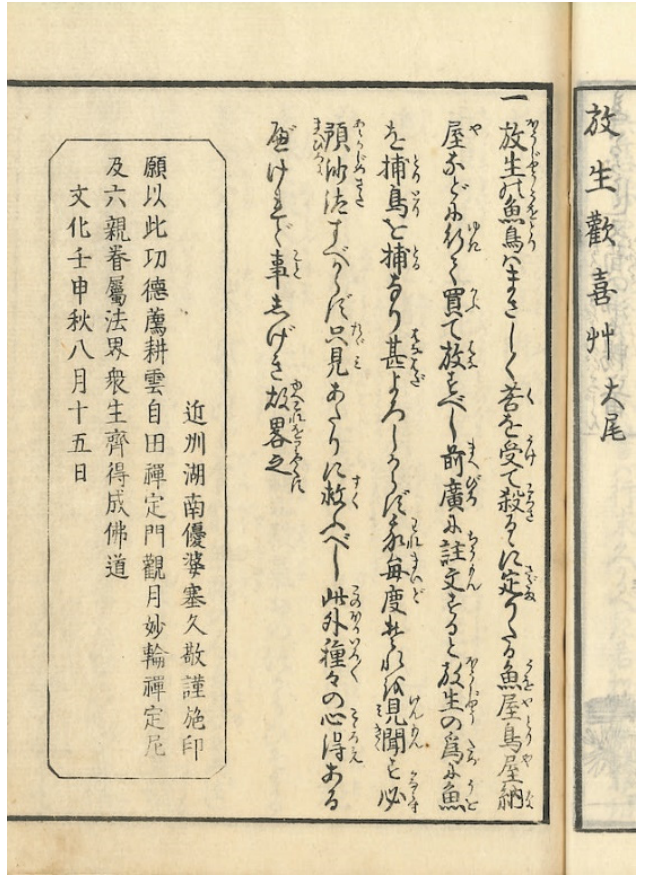

(a)

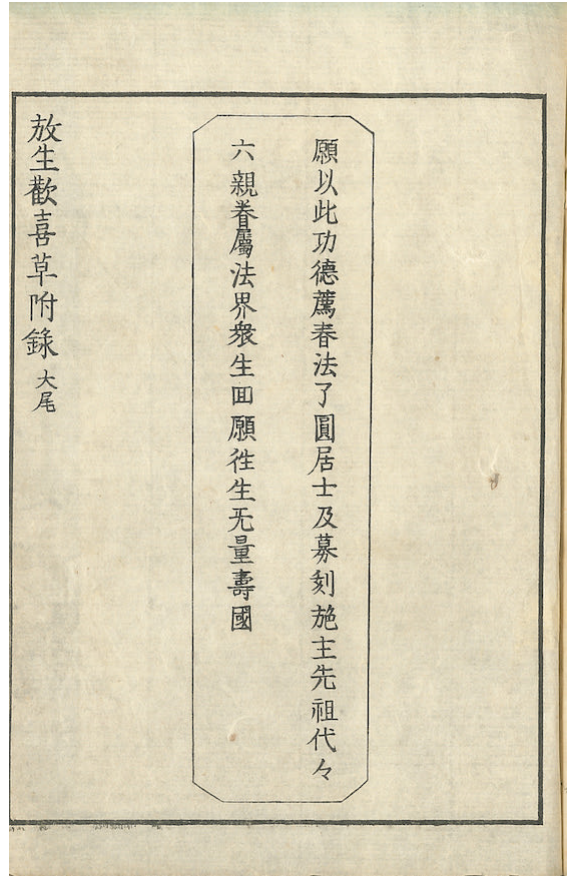

(b)

Figure 6. The colophons of the main text (a) and the appendix (b) of the 1812 edition of Junshō's Jottings on the Joys of Life Releases. The printing of the main text was sponsored by a devout layman (J. ubasoku) from Ōtsu, who may be identical to the layman Tetsuō who inspired the publication. The merit of the printing of the main text and the appendix was dedicated to the salvation of the sponsors' relatives. The colophon of main text wished that a layman, Kōun Jiden Zenjōmon, and a laywoman, Kangetsu Myōrin Zenjōni, will attain posthumous merit, while the colophon of the appendix expressed the wish that a layman, Shunhō Ryōen Koji, and ancestors of the sponsor would achieve rebirth in Amitābha's pure land. The three beneficiaries mentioned by their posthumous names were likely very close family members of the sponsors. In addition, the printing was also dedicated to the sponsors' six relations by blood and marriage (parents, siblings, spouses, and children) and all living beings. The printing was dated the fifteenth day of the eighth month of Bunka 9. The day was associated with life releases because the annual release at the Iwashimizu Hachiman Shrine. (Original in author's collection.)

In a similar vein, late-Edo-period tracts on refraining from killing and releasing often included a formulaic list of blessings generated by life releases-riches and honors, longevity, descendants, and business success - that was juxtaposed with an inverse list of retribution for killing living beings-short lifespans, poverty, illness, and bad fortune. These benefits closely resemble the Chinese precedent, but since the target audience included mostly townspeople and peasants in Japan, the attainment of official positions played a minimal role. Instead, the emphasis shifted to wealth, business success, and social status in general. One early example of this formulaic list appeared in the opening chapter of Jishū's Compendium:

People who always accord with the hearts of the various gods will have riches and honors, longevity, descendants, and prosperity. There will not be anything inauspicious in their families. They will be born in a good place in a future life. By contrast, evil people who associate with evil spirits will have short lifespans, poverty, and inauspiciousness, and will face the retribution of extreme suffering in future lives. (Jishū 1783, pp. I.2b-3a)

Similar lists of benefits and retribution also appear in later tracts, and these blessings and punishments were said to affect not only the person in question but also their family members. For instance, in addition to encouraging devotees to conduct life releases for the 
repose of the ancestors, Junshō also credited releases with attaining good health, long lives, good fortune, and descendants (Junshō 1812, 7a-7b; Junshō 1816, 5a, 6b, 8a). In the 1816 edition, an illustration that accompanies his discussion of these benefits depicted a wealthy multi-generational family gathered around a celebratory meal with the following caption (Figure 7):

The karmic rewards of releasing life are truly fortunate: you will attain longevity, good health and avoid illness. Your family will attain riches and honors. Your descendants will spread their wings like cranes and your family's fortune will be inherited for a long time. You shall always cheer with celebration. Therefore, you should save the lives of living beings on behalf of your ancestors, your descendants, and for posthumous merit. (Junshō 1816, pp. 8b-9a)

The family depicted in the image had clearly attained these blessings, and the image on the opposite page showed a happy couple releasing fish, turtles, and birds into a river.

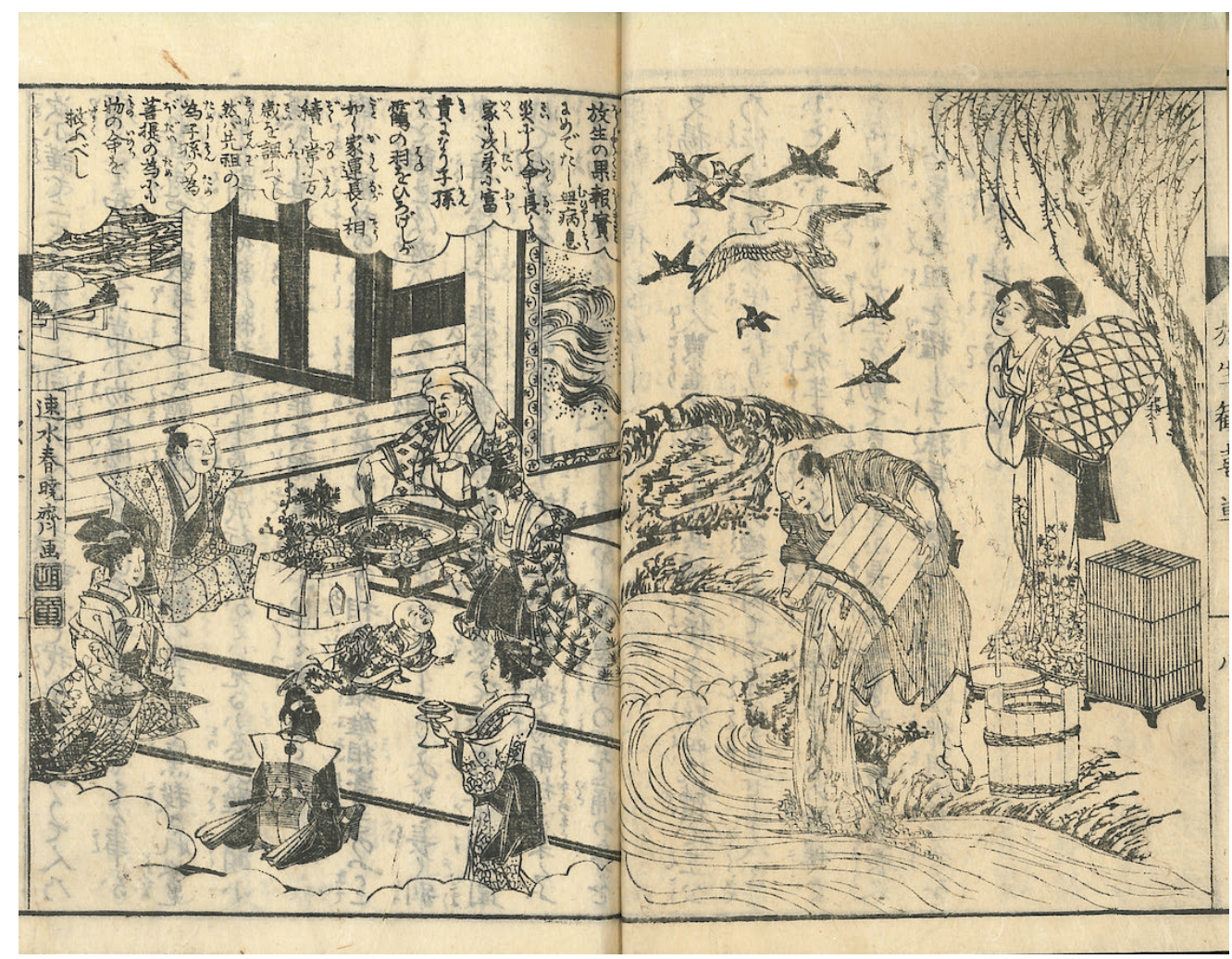

Figure 7. Illustration of the karmic benefits of life releases in Junshō's Jottings on the Joys of Life Releases (1816). (Original in author's collection.)

Conversely, an image illustrating the punishments for killing showed the family of a hunter, who were depicted as poor, disheveled, ill, and disabled (Figure 8). Their house was dilapidated, and creditors were calling to collect debts. The caption reads:

The karmic retribution for killing is truly disgraceful: your family will be poor. Your children will be born crippled. You will suffer from severe illnesses and poverty. You will live lacking honor and position. Being in this world will not be worth it. (Junshō 1816, 14b)

The family's transgressions were clearly visible: a hunting rifle was displayed on the wall, a turtle pierced with a knife and an eel killed with a spiking tool sat on a cutting board, and a deer leg rested on the veranda. Thus, late-Edo-period tracts promoted the idea that wealth and physical well-being were intimately linked with morality and could be achieved by the performance of good deeds, including refraining from killing and releasing life. 


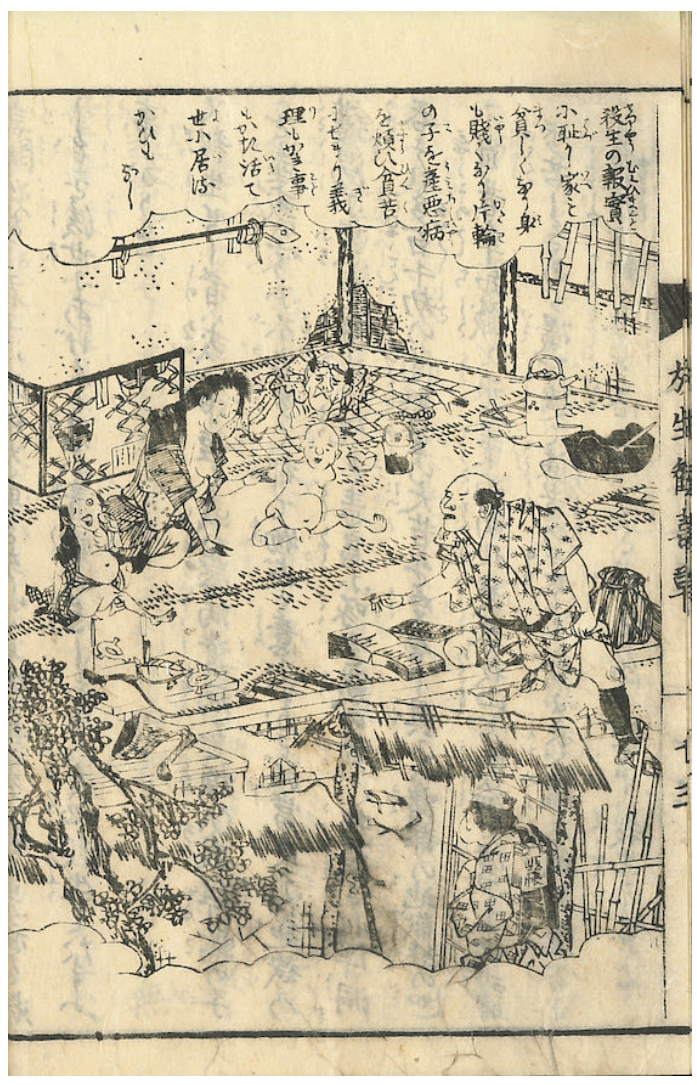

Figure 8. Illustration of the karmic retribution for killing living beings in Junshō's Jottings on the Joys of Life Releases (1816). (Original in author's collection.)

\section{Conclusions}

As scholars have shown, Ming-Qing Buddhism had a significant influence on early modern Japanese Buddhism, particularly on Zen. The encounter with the Ōbaku lineage spurred interest in the observance of the precepts, monastic reforms, and a growing sense of sectarian identities within Rinzai and Sōtō Zen (Baroni 2000, 2006; Riggs 2002, 2004; Baskind 2006; Wu 2014; Nogawa 2016a). Though also initiated by Ōbaku clerics, the introduction and reception of Zhuhong's Tract on Refraining from Killing and on Releasing Life provides us with a different window into the cultural and religious transmission from China to Japan during the Edo period-one that is less focused on sectarian identities because of its trans-sectarian appeal and lay focus.

Soon after Ming-Qing Buddhist texts, including morality books and merit ledgers, appeared in China, they were reprinted in Sino-Japanese and then issued in accessible vernacular editions that adapted and merged them with texts on similar topics. Eventually, Japanese Buddhist clerics wrote their own vernacular tracts that referenced the Chinese sources and added Japanese karmic tales of recent origins. Through this process, Ming-Qing Buddhist concepts, such as Zhuhong's ethic of refraining from killing and releasing life and the unity of the Three Teachings, had a significant influence on Japanese Buddhism and may even have been an impetus for Tsunayoshi's Laws of Compassion. By the end of the early modern period, Zhuhong's ethic had become thoroughly assimilated across a variety of Buddhist denominations and into popular religious practice, and life releases were viewed as means for attaining a range of vital benefits from longevity to the posthumous repose of the ancestors.

Notably, these Buddhist tracts did not strongly emphasize the differences between Chinese and Japanese eating habits and their karmic effects. Nineteenth-century Japanese Confucian and Nativist scholars sometimes contrasted purportedly more carnivorous Chinese eating habits with the Japanese diet of rice and fish to argue for the moral superiority 
of the Japanese (Krämer 2008, pp. 50-52). By contrast, these Sinophile Buddhist writers emphasized the parallels between China and Japan by providing examples of karmic retribution and rewards in both countries in order to prove the veracity of Zhuhong's ethic of refraining from killing and releasing life.

Buddhist proponents of the ethic of refraining from killing and releasing life were aware that their position resisted the predominant social practice of killing and consuming animals in Japan. Yinyuan's pleas to abolish animal slaughter in Nagasaki, which he later blamed for a fire that destroyed the better part of the city in 1663, fell on deaf ears with the local officials (Wu 2014, pp. 150-51). Asai Ryōi's contemporaries in the mid-seventeenth century may have abstained from meat on the death anniversaries of their ancestors but consumed fish and fowl on other days (Asai 2013, p. 437). Writing in the late seventeenth century, Dokuan understood that despite Tsunayoshi's Laws of Compassion, the prevailing custom of his day was to kill animals rather than the practice of benevolence and righteousness (Dokuan 1692, p. iv.a). In the late eighteenth century, Tainin's lay interlocutor posed several questions about how to defend the Buddhist position on refraining from killing when most people killed and ate fish and fowl and thought of these animals as having been supplied by heaven for human consumption (Tainin 1784, pp. $4 \mathrm{~b}, 7 \mathrm{a})$. Approximately 120 years later, Taikyo likewise knew that he was arguing against the overwhelming forces of modernization and the adoption of Cartesian rationalism that denied that animals had spirits and thus allowed for their unbridled consumption (Taikyo 1898, p. 50). What is perhaps most surprising is that the influence of Zhuhong and the morality book literature lasted well into the Meiji period until modernizing trendsincluding the decriminalization and widespread acceptance of meat eating among the clergy (Jaffe 2005)—eventually made Zhuhong's ethic and its literalist representation of karmic retribution less appealing to modernist Japanese Buddhist clerics.

Funding: This research received no external funding.

Conflicts of Interest: The author declares no conflict of interest.

\section{Notes}

1 I would like to thank Kikukawa Ichidō and Ryūkoku University's Sekai Bukkyō Bunka Sentā, as well as my colleague Richard Jaffe at Duke University, for arranging access to Dokuan's Kaisetsu hōjō mon hen for me. I am also grateful to the Ishikawa Kenritsu Rekishi Hakubutsukan for granting me access to Zenseki's Kaisetsu hōjō mon wage. Without their generosity, the scope of this research project would not have been possible during the COVID pandemic.

2 As I demonstrated in an earlier publication, memorial rites for animals such as whales, livestock, and pets emerged during this period (Ambros 2012). Though none of the primary sources I consulted made this connection explicit, it is likely that these morality books and merit ledgers, including Zhuhong's Record, also played a role in the emergence of such rites. After all, Zhuhong's Record states that burial and commemoration of dead animals accrued merit, and animal memorial rites became widespread from the late eighteenth century onward when this Ming-Qing morality books gained traction in Japan.

3 Hōjō Hideo notes that the work cannot be certified as having been composed by Asai with absolutely certainty but was likely composed by him as it dates from the period in which he was most active and matches his style (Hōjō 1972, pp. 51-52); most scholars, however, assume that Ryōi authored this text, and I follow this attribution.

4 Kaien Ekū also administered the precepts to the teacher of Tainin's teacher. Tainin, another Shingon Ritsu cleric, later authored an influential text on releasing life, Guide to Releasing Life, which I discuss below (Kawaguchi 1994).

5 Taikyo's argument against the modernizers is reminiscent of Zhuhong's debate with Matteo Ricci in the late Ming on the topic of killing and releasing animals, which Zhuhong addressed in a chapter titled "On Heaven" in the third volume of his Jottings by a Bamboo Window. Matteo Ricci had argued that it was permissible for humans to kill animals for human needs while Zhuhong had insisted that killing animals was a transgression and humans and animals shared kinship bonds through the cycle of death and rebirth (Yü [1981] 2020, pp. 92-95).

$6 \quad$ Jishū identified a large variety of Tang and Song sources, but some of these tales may have been excerpted from Ming collections. For instance, Jishū cited some of the tales that appeared in Zhuhong's Tract as being derived from earlier sources rather than from Zhuhong's text. Moreover, Jishū credited several anomaly accounts that were originally from the Mingbao ji (Record of supernatural retribution) but had only survived in the Daoshi's Fayuan zhulin (Forest of gems in the garden of the dharma, 668), which was used in the Ming to reconstruct earlier records of anomalies, to the original source rather than Daoshi. 
7 In Indian Buddhism, the laity was encouraged to observe the Eight Precepts on uposadha days, which of course included the precept against killing. In the Kamakura period, the six upoṣadha days had been associated with prohibitions against hunting and other forms of killing (Nakazawa 2000, pp. 250-51).

\section{References \\ Primary Sources}

Asai, Ryōi 浅井了意. 2013. Asai Ryōi zenshū: Kanazōshi hen 浅井了意全集一仮名草子編. Tokyo: Iwata Shoin, vol. 4.

Ciyun 慈雲. Jinyuan ji 金園集 3 vols. X.57, no. 950. Available online: http://tripitaka.cbeta.org/X57n0950 (accessed on 15 August 2021).

Dokuan 独庵. 1692. Kaisetsu hōjō mon hen 戒殺放生文篇. Kyoto and Edo: Dōdabō Kandōken, Murakami Genbee.

Enkyō 円鏡. 1964. Kaisetsu hōjō mon sange 戒殺放生文纂解. Tokyo: Taishō Daigaku Chūgokugaku Kenkyūshitsunai Dōkyō Kankōkai. First published 1682.

Enkyō 円鏡. 1685. Bonmōkyō koshaku onchi 梵網経古迹温知. [n.p.]: Imai Gohee.

Gyokusui 玉水. 2013. Hōjō kanjin roku 放生勧進録. In Edo jidai shomin bunko, vol. 12: Bukkyō 江戸時代庶民文庫（1 2 ）一仏教. Edited by Koizumi Yoshinaga. Tokyo: Ōzorasha, pp. 194-206. First published 1851.

He, Longxiang 賀龍騍, ed. 1906-1917. Chongkan Daozang jiyao 重刊道藏輯要. Chengdu: Er Xian An, vol. 223. Available online: https:/ / repository.lib.cuhk.edu.hk/en/item/cuhk-57186 (accessed on 15 August 2021).

Jishū 慈周. 1783. Hōjō kudoku shū 放生功徳集. 3 vols. Kyoto, Osaka and Edo: Akitaya Heizaemon, Kashiya Kihee, Kashiwaraya Yozaemon, Suharaya Ihachi.

Jishū 慈周. n.d. Kange seppō innen shū 钦化説法因縁集. 3 vols. [n.p.]

Junshō 純爾. 1812. Hōjō yorokobi gusa 放生歓喜顺. Ōtsu: [n.p.].

Junshō 純爾. 1816. Hōjō yorokobi gusa 放生歓喜草. Kyoto and Edo: Heian Shorin and Tōto Shorin.

Kaisetsu hōjō mon 誡殺放生文. 1836. Edo: Yōgyokuin Kōshin.

Kanjun 賽潤. 1803. Sankyō hōjō benwaku 三教放生辨惑. 4 vols. Kyoto and Osaka: Izumodera Bunjirō, Ogawa Gohee, Miki Anbee, Matumura Kyūhee, Yamawaki Seigorō.

Kasama, Ryūchō 笠間竜跳. 1884. Chikusō zuihitsu wage 竹空随筆和解. 5 vols. Nagoya: Shōshinkai Shuppankyoku.

Li, Yanshou 1639 李延壽. 1639. Bei shi 北史. Changshu: Ji Gu Ge, vol. 3. Available online: https://opacplus.bsb-muenchen.de/title/ BV037312043 (accessed on 15 August 2021).

Li, Zhi 李䞇. 2010. Li Zhi quanji zhu 李䞇全集注. Beijing: Shehui Kexue Wenxian Chubanshe, vol. 18.

Song, Lian 東濂. 1874. Yuan shi 元史. [n.p.]: Jiangsu shu ju.

Taikyo 太虚. 1898. Hōjō meikan roku 放生冥感録. Kōyamura: Entsūji.

Tainin 諦忍. 1784. Hōjō tebiki gusa 放生手引草. Nagoya: Fujiya Kichibee.

Yan, Maoyou 顏茂猷. n.d. Diji lu 廸吉. 8 vols. [n.p.]: Yanshi Cangban. Available online: https:/ /iiif.lib.harvard.edu/manifests/view / drs:53591150\$87i (accessed on 20 July 2021).

Yongjue 永覺. Jingci yaoyu 淨慈要語. X.61, no. 1166. Available online: http:/ / tripitaka.cbeta.org/X61n1166 (accessed on 15 August 2021).

Zenseki 杜多善積. 1744. Kaisetsu hōjō mon wage 戒殺放生文和解. Edo: Anshōji.

Zhu, Mu 祝穆. 1666. Xinbian gujin shiwen leiju houji. vols. 32-34. Kyoto: Hachio Kanbee. Available online: https://hdl.handle.net/2027 / keio.10812718445 (accessed on 15 August 2021).

Zhuhong 袾宏. Fangsheng yi 放生儀. Yunqi fahui 雲棲法彙. J.32, no. B277, vol. 10. Available online: http://tripitaka.cbeta.org/ja/J3 2nB277_010 (accessed on 20 July 2021).

Zhuhong 袾宏. Jiesha fangsheng wen 戒殺放生文. Yunqi fahui 雲棲法彙. J.32, no. B277, vol. 11. Available online: http://tripitaka.cbeta. org/J32nB277_011 (accessed on 20 July 2021).

Zhuhong 袾宏. Yigao 遺稿. Yunqi fahui 雲棲法彙. J.33, no. B277, vol. 21. Available online: http://tripitaka.cbeta.org/J33nB277_021 (accessed on 1 July 2021).

Zhuhong 袾宏. Zizhi lu 自知. Yunqi fahui 雲棲法彙. J.32, no. B277, Vols. 8 and 9. Available online: http://tripitaka.cbeta.org/J32nB277 _008; http:/ / tripitaka.cbeta.org/J32nB277_009 (accessed on 20 July 2021).

Zhuhong 袾宏. 1661. Kaisetsu hojjo mon 戒殺放生文. [n.p.]

Zhuhong 袾宏. 1701. Jichiroku 自知録. Kyoto: Shōrensha.

Zhuhong 袾宏. 1800. Zōho eshō waji kōga jichiroku 增補絵抄和字功過自知録. Kyoto, Edo, and Osaka: Takemura Shinbee, Akamatsu Kuhee, Asano Yahee, and Morimoto Tasuke.

Zongben 宗本. Guiyuan zhizhi ji 蹛元直指集. X.61, no. 1156, Vols. 1 and 2. Available online: http://tripitaka.cbeta.org/X61n1156 (accessed on 15 August 2021).

\section{Secondary Sources}

Ambros, Barbara R. 2012. Bones of Contention: Animals and Religion in Contemporary Japan. Honolulu: University of Hawai'i Press.

Ambros, Barbara R. 2019. Cultivating Compassion and Accruing Merit: Animal Releases during the Edo Period. In The Life of Animals in Japanese Art. Edited by Robert T. Singer and Kawai Masatomo. Princeton: Princeton University Press, pp. 16-27.

Baroni, Helen. 2000. Obaku Zen: The Emergence of the Third Sect of Zen in Tokugawa Japan. Honolulu: University of Hawai'i Press. 
Baroni, Helen. 2006. Iron Eyes: The Life and Teachings of Obaku Zen Master Tetsugen Doko. Albany: State University of New York Press.

Baskind, James Matthew. 2006. Ming Buddhism in Edo Japan: The Chinese Founding Masters of the Japanese Obaku School. Ph.D. Dissertation, Yale University, New Haven, CT, USA.

Bodart Bailey, Beatrice. 1985. The Laws of Compassion. Monumenta Nipponica 40: 163-89. [CrossRef]

Brokaw, Cynthia J. 1991. Ledgers of Merit and Demerit: Social Change and the Moral Order in Late Imperial China. Princeton: Princeton University Press.

Dong, Hang 董航. 2018a. Asai Ryōi ni okeru Chūgoku minmatsu zensho bunka no shuyō: Yan Maoyou cho Diji lu o chūshin ni. 浅井 了意における中国明末善書文化の受容一顔茂猷著『廸吉録』を中心に. Ilbon Munhwa Hakbo 日本文化學報 79: 109-27.

Dong, Hang 董航. 2018b. Kagami gusa ni okeru Diji lu kara shakuyō mondai: Ryōha no hikaku kentō o chūushin ni.『鑑草』における 『廸吉録』からの借用問題一両者の比較検討を中心に. Seikei Jinbun Kenkyū 成蹊人文研究 26: 19-45.

Eichman, Jennifer. 2016. A Late Sixteenth-Century Chinese Buddhist Fellowship: Spiritual Ambitions, Intellectual Debates and Epistolary Connections. Leiden: Brill.

Fujikawa, Hideo 富士川英郎. 2012. Edo Kōki No Shijintachi 江戸後期の詩人たち. Tokyo: Heibonsha.

Handlin Smith, Joanna. 2009. The Art of Doing Good: Charity in Late Ming China. Berkeley: University of California Press.

Hōjō, Hideo. 1972. Asai Ryōi. Tokyo: Kasama Shoin.

Hōjō, Hideo. 1973. Asai Ryōi ikaden narabi ni shukke kō. 浅井了意叱伝並びに出家考. Tōkai Gakuen Joshi Tanki Daigaku Kiyō 東海学園女子短期大学紀要 8: 158-64.

Imazeki, Tenpō 今関天彭. 2015. Edo Shijin Hyōdenshū: Shishi “gay $\bar{u}$ ” shō 江戸詩人評层集: 詩誌「雅友」抄. Tokyo: Heibonsha, vol. 1.

Ishiguro, Kichijirō 石黒吉次郎. 2006. Sesshōtan no henbō (1): Chūsei kara kinsei e 殺生譚の変貌(1)中世説話から近世説話へ. Senshu Bungaku 専修国文 79: 21-40.

Ishiguro, Kichijirō 石黒吉次郎. 2007. Sesshōtan no henbō (2): Chūsei kara kinsei e 殺生譚の变貌(2)中世説話から近世説話へ. Senshū Bungaku 専修国文 81: 33-49.

Ishiguro, Kichijirō 石黒吉次郎. 2008. Sesshōtan no henbō (3): Chūsei kara kinsei e 殺生譚の変貌(3)中世説話から近世説話へ. Senshu Bungaku 専修国文 82: 41-61.

Jaffe, Richard. 2005. The Debate over Meat Eating in Japanese Buddhism. In Going Forth: Visions of Buddhist Vinaya. Edited by William Bodiford. Honolulu: University of Hawai'i Press, pp. 255-75.

Kawaguchi, Kōfū 川口高風. 1989. Tainin risshi to Zen sō to no kōryū. 諦忍律師と禅僧との交流. Indogaku Bukkyōgaku Kenkyū 印度学仏教学研究 38: 181-86.

Kawaguchi, Kōfū 川口高風. 1994. Tainin risshi no shi to deshi. 諦忍律師の師と弟子. Zen Kenyūsho Kiyō 禅研究所紀要 $23: 19-61$.

Kawaguchi, Kōfū 川口高風. 1995. Tainin Risshi Kenkyū 諦忍律師研究. Kyoto: Hōzōkan, vol. 1.

Kimura, Michiko 木村迪子. 2018. Asai Ryōi saku Kaisetsu monogatari, hōjō monogatari ni tsuite: Chūugoku jōdokyō shisō to no kankei ni chūmoku shite. 浅井了意作『戒殺物語・放生物語』について一中国浄土教思想との関係に注目して. Kokubungaku Kenkyū 国文学研究 186: 71-83.

Krämer, Hans Martin. 2008. "Not Befitting Our Divine Country": Eating Meat in Japanese Discourses of Self and Other from the Seventeenth Century to the Present. Food and Foodways 16: 33-62. [CrossRef]

Kurokawa, Yōichi 黒川洋一. 1990. Kan Sazan, Rikunyo 菅茶山・六如. Tokyo: Iwanami Shoten.

Legge, James, trans. 1885. The Sacred Books of China-The Texts of Confucianism, vol. 28: The Li Ki. Oxford: Clarendon Press.

Nagai, Masashi 永井政之. 1995. Dokuan Genkō to Chūgoku zen: Aru Nihon sō no Chūgoku bunka rikai. 独㢆立光と中国禅一ある日 本僧の中国文化理解. In Dokuan Genkō to Edo Shichō. 独庵立光と江戸思潮. Edited by Kagamishima Genryū. Tokyo: Perikansha, pp. 67-122.

Nakazawa, Katsuaki 中澤克昭. 2000. Sesshō to shinsei: Shuryō to nikushoku o meguru bakufu no tuzurafuji. 殺生と新制一狩猟と肉 食をめぐる幕府の葛藤. Tōhokugaku 東北学3: 247-59.

Nesaki, Mitsuo 根崎光男. 2006. Shōrui Awaremi No Sekai. 生類粼みの世界. Tokyo: Dōseisha.

Nishimura, Ryō 西村玲. 2012. Fusesshō to hōjōe 不殺生と放生会. Eco-Philosophy Kenkyū エコ・フィロソフィ研究 6: 47-53.

Nishimura, Ryō 西村玲. 2014. Nihon ni okeru fusesshō shisō: Unsei Shukō no shuyō to eikyō. 日本近世における不殺生思想一雲棲袾 宏の受容と影偣. Indogaku Bukkyōgaku Kenkyū 印度學佛教學研究 62: 753-57.

Nishimura, Ryō 西村玲. 2016. Kinsei ni okeru fusesshō shisō no hatten: Sankyō hōjō benwaku ni tsuite. 日本近世における不殺生思想の 展開: 『三教放生辨惑』について. Shūkyō Kenkyū 宗教研究 89: 323-24.

Nogawa, Hiroyuki 野川博之. 2016a. Minmatsu Bukkyō no Edo Bukkyō ni Taisuru Eikyō 明末仏教の江戸仏教に対する影響. Tokyo: Sankibō Busshorin.

Nogawa, Hiroyuki 野川博之. 2016b. Riben 17 shiji yihou de jiesha husheng sixiang: Yi Tokugawa Tsunayoshi wei zhongxin 日本 17 世紀以降的戒殺護生思想—以川綱吉為中心. Yuanguang Foxue Xuebao 圆光佛學學報 27: 107-54.

Ogawa, Takehiko 小川武彦. 1975. Asai Ryōi no nicho ni tsukite: Kaisetsu hōjō mon kana to Deki saikyō miyage. 浅井了意の二著につき て一戒殺放生仮名と出来斎京土産. Kinsei Bungei Kenkyū to Hyōron 近世文芸研究と評論 8: 23-37.

Ogawa, Takehiko 小川武彦. 1993. Asai Ryōi Kaisetsu monogatari hōjō monogatari to Shukō Kaisetsu hōjō mon. 浅井了意『戒殺物語放生物 語』と袾宏『戒殺放生文』. In Kanazōshi Shūsei. 假名草子集成. Edited by Asakura Haruhiko. Tokyo: Tōkyōdō Shuppan, vol. 4, pp. 421-35.

Okada, Takehiko 岡田武产, and Kengo Araki 荒木見悟, eds. 1984. Kinsei Kanseki Sōkan: Wakoku Eiin Shiso 4 hen 6 近世漢籍叢刊: 和刻影印 思想4編 6. Kyoto: Chūbun Shuppansha. 
Riggs, David E. 2002. The Rekindling of a Tradition: Menzan Zuihō and the reform of Japanese Sōtō Zen in the Tokugawa Era. Ph.D. Dissertation, University of California, Los Angeles, CA, USA.

Riggs, David E. 2004. The Life of Menzan Zuihō, Founder of Dōgen Zen. Japan Review 16: 67-100.

Stevenson, Daniel, trans. 2004a. Against Animal Sacrifice. In Buddhist Scriptures. Lopez, Donald, ed. New York: Penguin, pp. 403-15.

Stevenson, Daniel, trans. 2004b. Freeing Birds and Fish from Bondage. In Buddhist Scriptures. Lopez, Donald, ed. New York: Penguin, pp. 394-401.

Wu, Jiang. 2014. Leaving for the Rising Sun: Chinese Zen Master Yinyuan and the Authenticity Crisis in Early Modern East Asia. New York: Oxford University Press.

Yanagida, Naomi 柳田直美. 2015. Tokugawa Tsunayoshi jukyōteki tōji to Chūgoku zensho no shuyō ni tsuite. 徳川綱吉の儒教的統治 と中国善書の受容について. Gengo Bunka Shakai 言語・文化・社会13: 1-29.

Yü, Chün-fang. 2020. The Renewal of Buddhism in China: Zhuhong and the Late Ming Synthesis. New York: Columbia University Press. First published 1981. 